\%

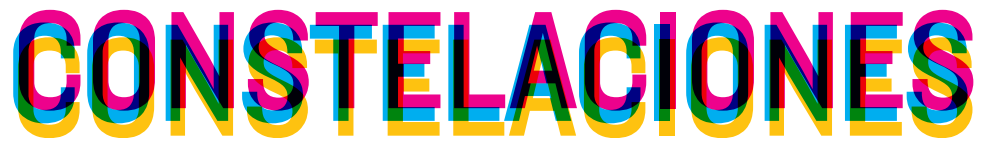

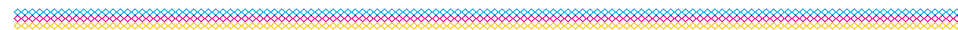


CONSTELACIONES n², mayo 2014

Revista de Arquitectura de la Universidad CEU San Pablo

Architecture Magazine of CEU San Pablo University

Periodicidad anual

Annual periodicity

COMITÉ DE REDACCIÓN EDITORIAL COMMITTEE

\section{Director Director}

Juan García Millán

Jefa de Redacción Editor in Chief

Covadonga Lorenzo Cueva

Secretario de Redacción Editorial Clerk

Rodrigo Núñez Carrasco

Maquetación y producción Design and production

María Fernández Hernández

Vocales Board Members

Fernando del Ama Gonzalo. Escuela Politécnica Superior, Universidad CEU San Pablo, Madrid

Pablo Campos Calvo-Sotelo. Escuela Politécnica Superior, Universidad CEU San Pablo, Madrid

Alfonso Díaz Segura Escuela Superior de Enseñanzas Técnicas, Universidad CEU Cardenal Herrera, Valencia

Mayka García Hípola. Escuela Politécnica Superior, Universidad CEU San Pablo, Madrid

Sonia Izquierdo Esteban. Escuela Politécnica Superior, Universidad CEU San Pablo, Madrid

Javier Sáenz Guerra. Escuela Politécnica Superior, Universidad CEU San Pablo, Madrid

\section{CONSEJO EDITORIAL EDITORIAL BOARD}

Beatriz Colomina. School of Architecture, Princeton University, New Jersey

Carmen Díez Medina. Escuela de Ingeniería y Arquitectura, Universidad de Zaragoza

María Antonia Frías Sargadoy. Escuela Técnica Superior de Arquitectura, Universidad de Navarra

Ángel González García. Facultad de Geografía e Historia, Universidad Complutense de Madrid

Juan Miguel Hernández Léon. Escuela Técnica Superior de Arquitectura, Universidad Politécnica de Madrid

Juan José Lahuerta Alsina. Escuela Técnica Superior de Arquitectura, Universidad Politécnica de Cataluña, Barcelona

Eduardo Leira Sánchez. Ex director del Plan General de Ordenación Urbana, Madrid

Joaquín Medina Wamburg. Facultad de Aquitectura Diseño y Urbanismo, Universidad de Buenos Aires

Zaida Muxí Martínez. Escuela Técnica Superior de Arquitectura, Universidad Politécnica de Cataluña, Barcelona

José Joaquín Parra Bañón. Escuela Técnica Superior de Arquitectura, Universidad de Sevilla

Víctor Pérez Escolano. Escuela Técnica Superior de Arquitectura, Universidad de Sevilla

Fernando Pérez Oyarzún. Escuela de Arquitectura y Diseño, Pontificia Universidad Católica, Santiago de Chile Judith Sheine. School of Architecture and Allied Arts, University of Oregon, Portland

Andrés Walliser Martínez. Global Design, New York University, Nueva York

\section{ISSN 2340-177X}

Depósito legal M-13872-2013

(c) de los textos, sus autores

(c) de las imágenes autorizadas

(c) Revista Constelaciones

๑) Escuela Politécnica Superior, Universidad CEU San Pablo

Universidad CEU San Pablo

Escuela Politécnica Superior

Urbanización Montepríncipe, $s / n$

Boadilla del Monte, 28668. Madrid (España)

constelaciones@eps.ceu.es

www.uspceu.es

Edición Edition

Fundación Universitaria San Pablo CEU

Madrid, España

Impresión Printing

VA Impresores

Impreso en España Printed in Spain

Distribución Distribution

CEU Ediciones

Los textos que componen Constelaciones se obtienen mediante convocatoria pública. Para que los trabajos recibidos entren en el proceso de selección de los artículos a publicar deben ser trabajos originales no publicados anteriormene, con una extensión recomendada de 3.000 palabras, título, resumen (un máximo de 150 palabras) y palabras clave (un mínimo de cuatro palabras), en español y en inglés. Tras haber cumplido estos requisitos (y los correspondientes incluidos en las normas editoriales de la revista, disponibles para consulta en formato digital desde el comienzo de la convocatoria), tiene lugar un proceso de revisión y evaluación de los artículos previa aceptación de los mismos para su publicación. Para acometer dicho proceso, y con el fin de asegurar la calidad de los contenidos, la Revista Constelaciones recurre a evaluadores externos a la institución editora y anónimos (cada artículo es evaluado por dos de ellos) encargados de someter a crítica los mismos. Todos los artículos de investigación publicados en esta revista han pasado por dicho proceso. La recepción de artículos se extendió hasta el 30 de Septiembre de 2013. Texts included in Constelaciones are obtained by public announcement. Only original papers that have not been previously published will be included in the process of selection of articles. They should not exceed 3.000 words and should include a title, an abstract (no more than 150 words) and keywords (a minimum of four words), in Spanish and English. After having fulfilled these requirements (and those included in magazine editorial standards, available for consultation from the beginning of the Call for Papers), occurs a process of review and evaluation of articles upon acceptance of them for publication. To undertake this process, and in order to ensure the quality of the contents, Constelaciones turns to external and anonymous evaluators to the institution (each article is evaluated by two of them) responsible for the critic. All the articles published in this journal have undergone this process. The deadline for reception was extended until September 30, 2013.

Todos los derechos reservados. Esta publicación no puede ser reproducida, ni en todo ni en parte, ni registrada, ni transmitida, ni almacenada en ningúna forma ni por ningún medio, sin la autorización previa y por escrito del equipo editorial. En este número se han utilizado algunas imágenes de las que no se ha podido identificar al propietario de los derechos. En estos casos hemos entendido que las imágenes son de libre uso. En caso de identificar alguna de estas imágenes como propia, por favor, póngase en contacto con la redacción de Constelaciones. Los criterios expuestos en los diversos artículos de la revista, son responsabilidad exclusiva de sus autores, y no reflejan necesariamente los que pueda tener el equipo editoral. El equipo editorial de la revista no se responsabiliza de devolver la información enviada a la redacción a no ser que se le solicite expresamente. All rights reserved. This publication cannot be reproduced, in whole or in part, nor registered, transmitted or stored in any form or by any means, without the written permission of the Editorial team, In this issue some images were used without knowing the owner of the rights. In these cases, we have understood that the images are free of use. In case you identify written permission of the Editorial team, In this issue some images were used without knowing the owner of the rights. In these cases, we have understood that the images are free of use. In case you identify
any of these images as your own, please, contact with the Editorial staff of Constelaciones. The opinions expressed in this issues's articles are entirely the responsibility of their authors and are not necessarily shared by the editors of this journal. The publisher don't take responsibility for returning submitted material which is not expressly requested. 


$$
11
$$




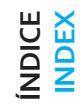

$\stackrel{n}{\sim}$

ร

5

$\curvearrowright$

๙ิ

$\stackrel{n}{=}$

$\bar{m}$
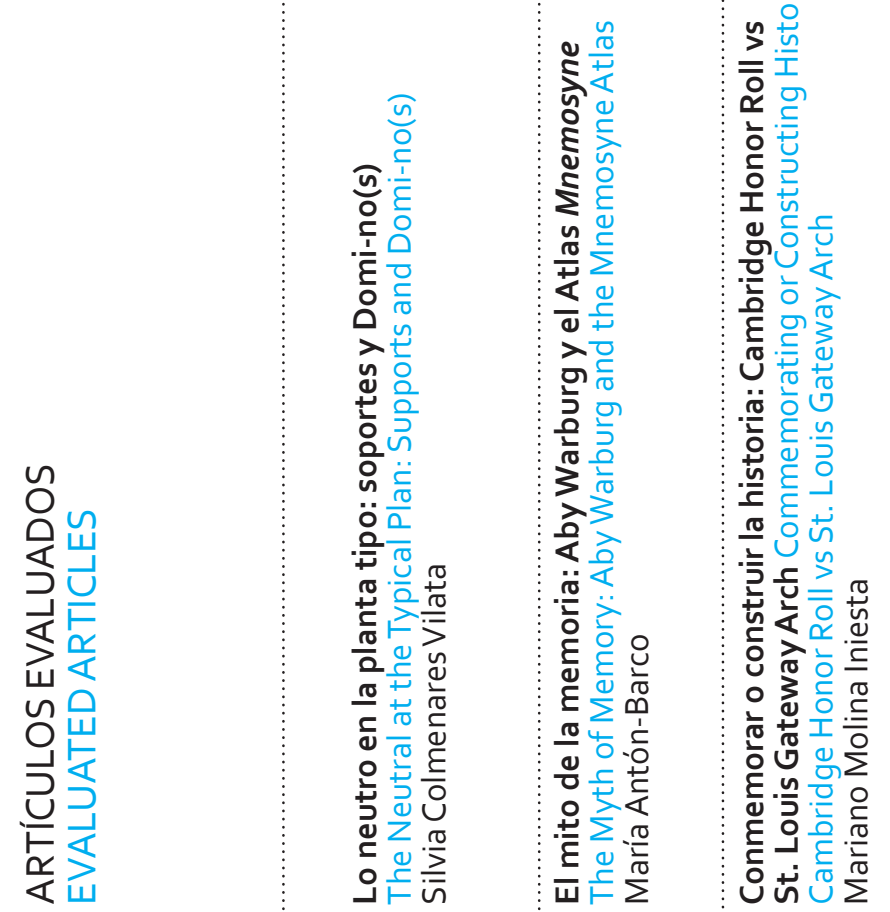

旁 을

‥

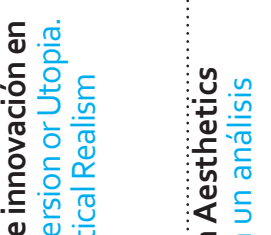

앙

胥苞

$\bar{\Psi}$

宛

일

능홍

区告

음 흠

응 흥

\%

든

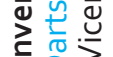

ข

음

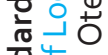

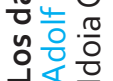

a व

은

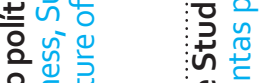

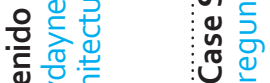

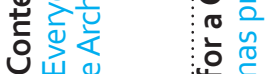

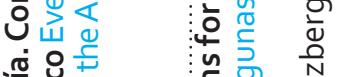

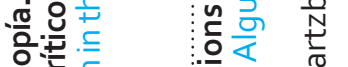

गे

गे० गे ये ज

:

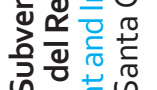

है

ज०

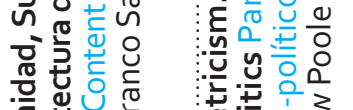

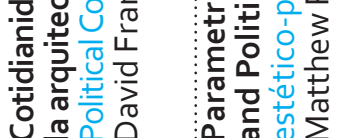

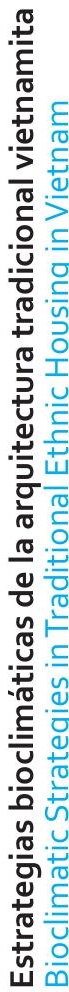

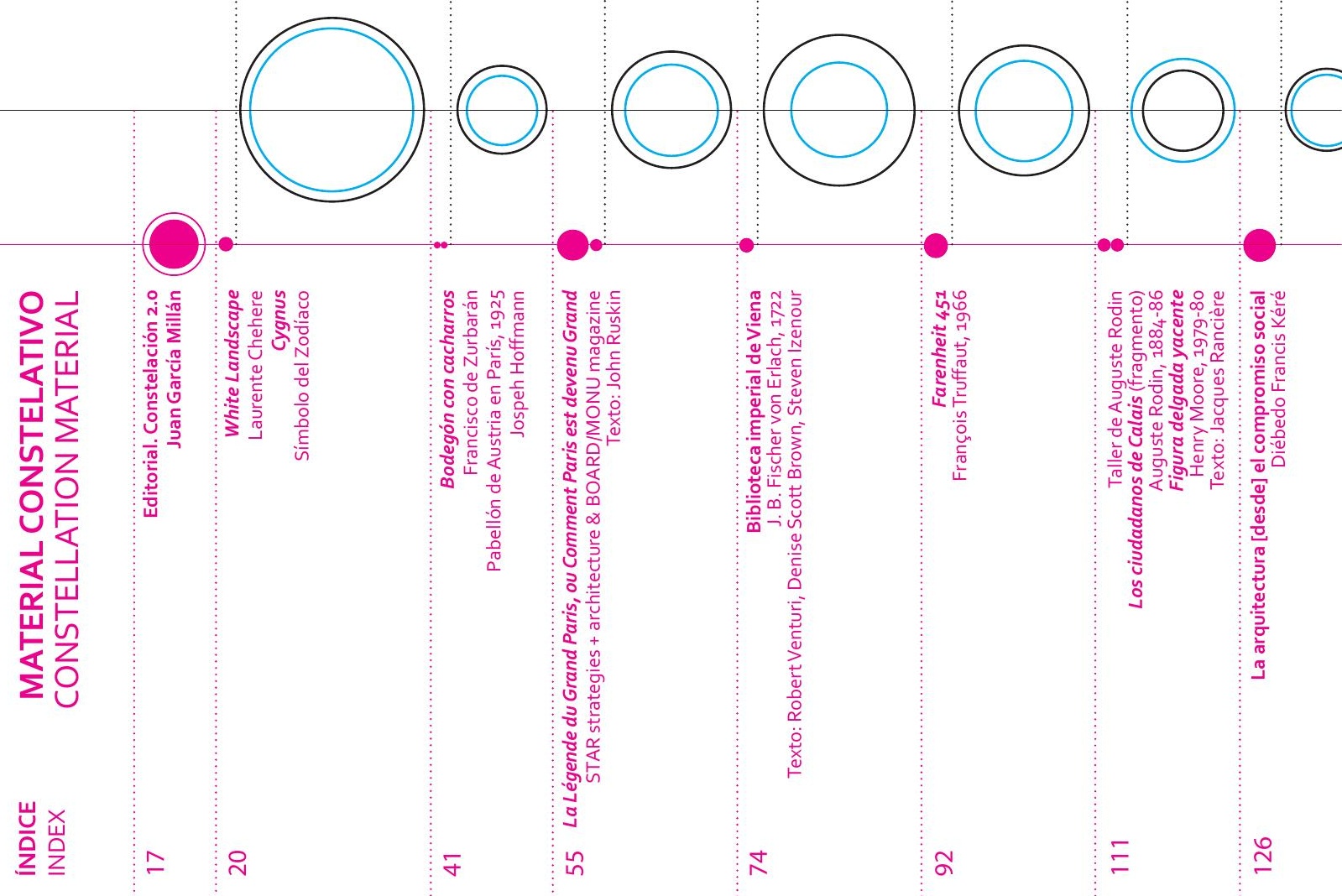

苍

० 


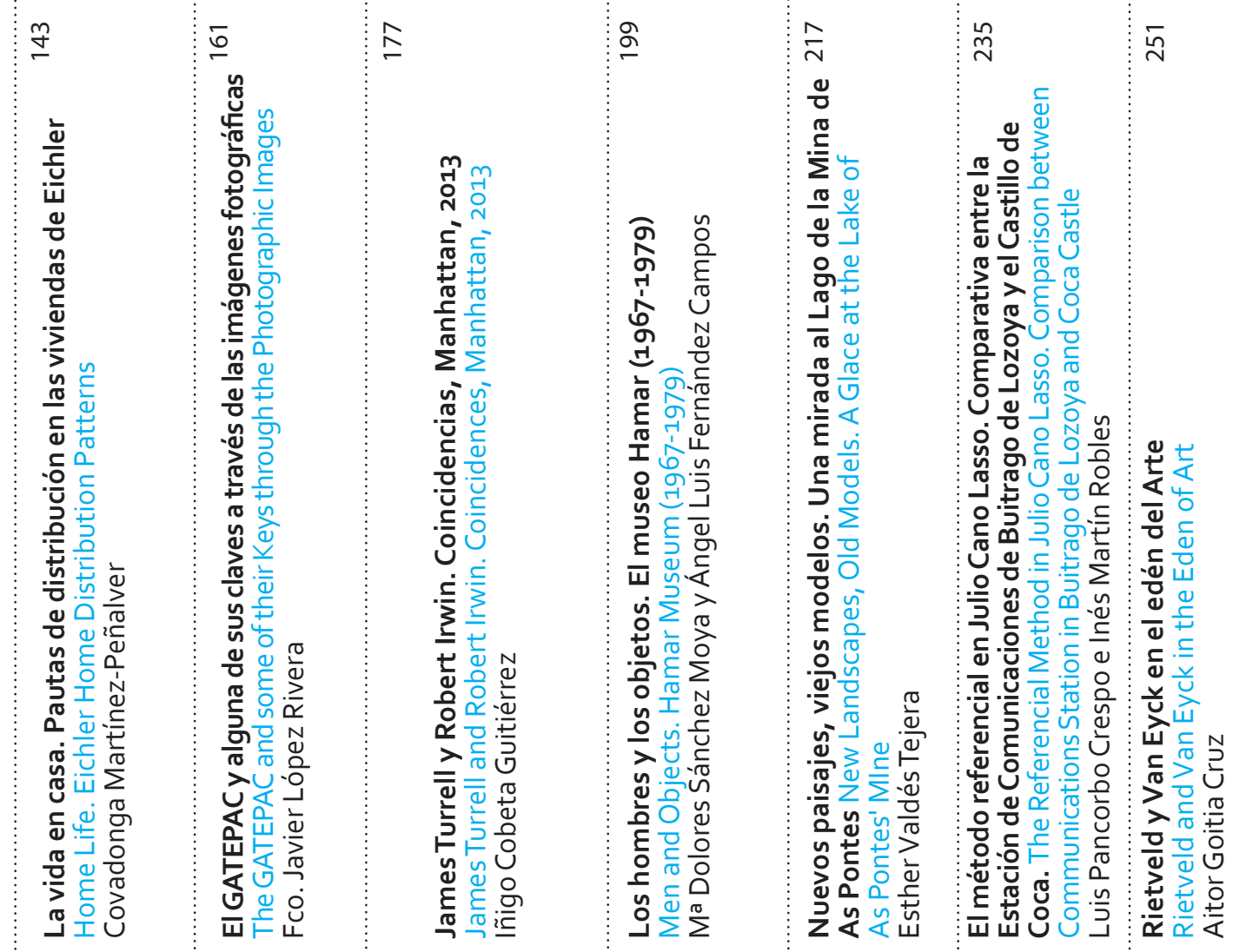
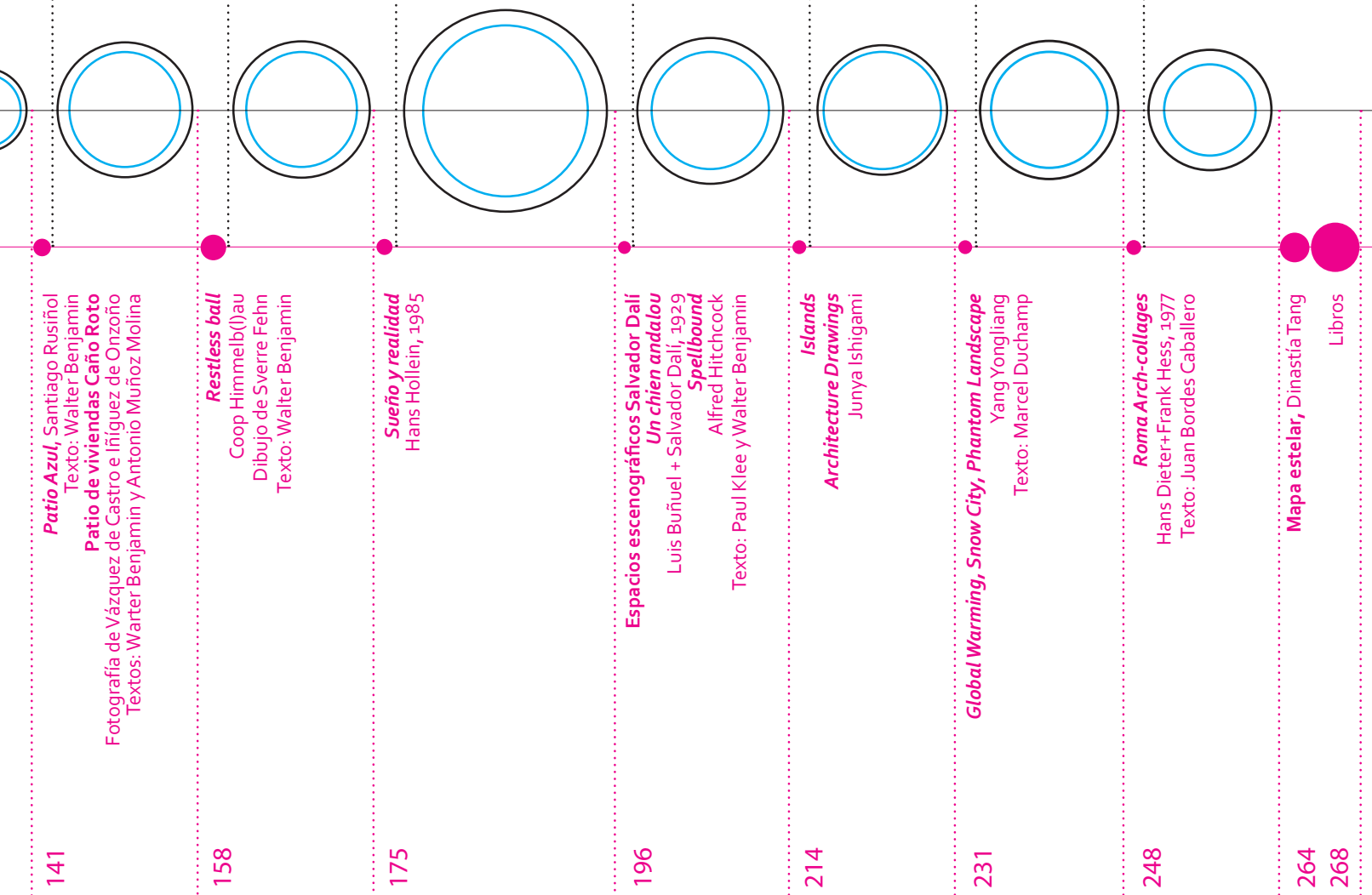


\section{Lo neutro en la planta tipo: soportes y Domi-no(s) The Neutral at the Typical Plan: Supports and Domi-no(s)}

\section{Silvia Colmenares Vilata}

Escuela Técnica Superior de Arquitectura, Universidad Politécnica, Madrid.

Traducción Translation Silvia Colmenares Vilata

\section{Palabras clave Keywords}

Neutro, tipo, genérico, estructura, infraestructura, planta libre, planta tipo, Dom-ino, soporte Neutral, type, generic, structure, infrastructure, free plan, typical plan, Dom-ino, support

\section{Resumen}

Desde la hipótesis de lo 'neutro' como posibilidad para la arquitectura, el texto explora el camino recorrido desde la 'planta tipo', característica de la edificación en altura y teorizada por primera vez de forma retroactiva por Rem Koolhaas, hacia la noción de 'soporte infraestructural', enunciada en el contexto de la reconstrucción de la ciudad europea tras la Segunda Guerra Mundial por John Habraken. Un camino que está presidido por la referencia constante a los principios modernos de 'planta libre' expresados de forma esencial por Le Corbusier en el esquema Dom-ino, que se constituye así como 'tipo' en torno al cual gravitan los argumentos, en ocasiones contradictorios, que promueven la indiferencia funcional como mecanismo de neutralización de la planta.

\section{Abstract}

From the hypothesis of the neutral as a possibility for architecture, the text explores the path between the 'typical plan', as distinctive of the tall office building and retroactively theorized by Rem Koolhaas, to the notion of infrastructural 'support', as defined at the context of the reconstruction of the European city after the Second World War by John Habraken. This path is presided by the permanent reference to the modern principles of the 'free plan' as essentially expressed by Le Corbusier in the dom-ino scheme. Thereby, the scheme itself becomes a 'type' around which gravitate even contradictory arguments promoting functional indeterminacy as a mechanism to neutralize the plan. 
"Sólo se puede estar en la planta tipo.

Ni dormir, ni comer, ni hacer el amor"

Rem Koolhaas (1)

No parece casual que el padre de la biométrica fuera primo de Darwin. Ni que su obsesión por el estudio de la diferencia le condujera directamente hacia el concepto de media aritmética. Cuando Francis Galton (2) realizaba sus famosos 'retratos compuestos' para identificar los rasgos característicos de determinados grupos humanos, recurrió a la superposición como herramienta básica para la comparación. Y la congruencia entre los distintos elementos superpuestos era la exigencia inmediata que demandaba el procedimiento.

La obtención de lo típico, entendida aquí como un proceso inductivo a partir de ejemplos concretos, es en gran medida una construcción irreal basada en el conocimiento de lo diferente, que permite sin embargo sacar factor común para delimitar los invariantes de cada una de las configuraciones de un determinado sistema. Por el contrario, el 'tipo ideal' es aquella combinación de características que, aunque no se da plenamente en ninguno de los individuos del conjunto, se define para representar a cualquiera de ellos porque sus rasgos tienden a aproximarse al él. Cuando uno de los individuos manifiesta una coincidencia radical con ese tipo ideal hablamos de arquetipo, y el primer individuo que consigue aproximarse recibe el nombre de 'prototipo'. (3) (Figs. 1, 2)

Distinguiremos por tanto dos aproximaciones al concepto de 'tipo': la primera, vinculada a la normalidad y la ausencia de atributos diferenciadores, que remite al sustrato lo genérico. La segunda, asociada con lo ejemplar y con la distinción entre conjuntos, que abunda en lo específico. Como dos

\footnotetext{
"You can only be in typical plan, not sleep, eat, make love"

Rem Koolhaas (1)
}

It does not seem accidental that the father of biometrics was Darwin's cousin. Neither that his obsession with the study of the difference leads him directly to the concept of arithmetic average. When Francis Galton (2) performed his famous 'composite portraits' to identify the defining features of certain human groups, he draw upon overlapping as a basic tool for comparison. And congruence between the various overlapping elements was the immediate requirement demanded by the procedure itself.

Obtaining the typical, understood here as an inductive procedure starting from concrete examples, is largely an unreal construction based on knowledge of the different. However, it allows bringing out common factor to define the invariants of each of the configurations of a given system. On the contrary, the 'ideal type' is that combination of features that, while not fully present in any given set of individuals, is defined to represent any of them, because their traits tend to become closer to it. When one of the individuals manifests a radical match with the ideal type, we talk about 'archetype', and the first one that reaches this closeness is called 'prototype'. (3) (Figs. 1,2) 

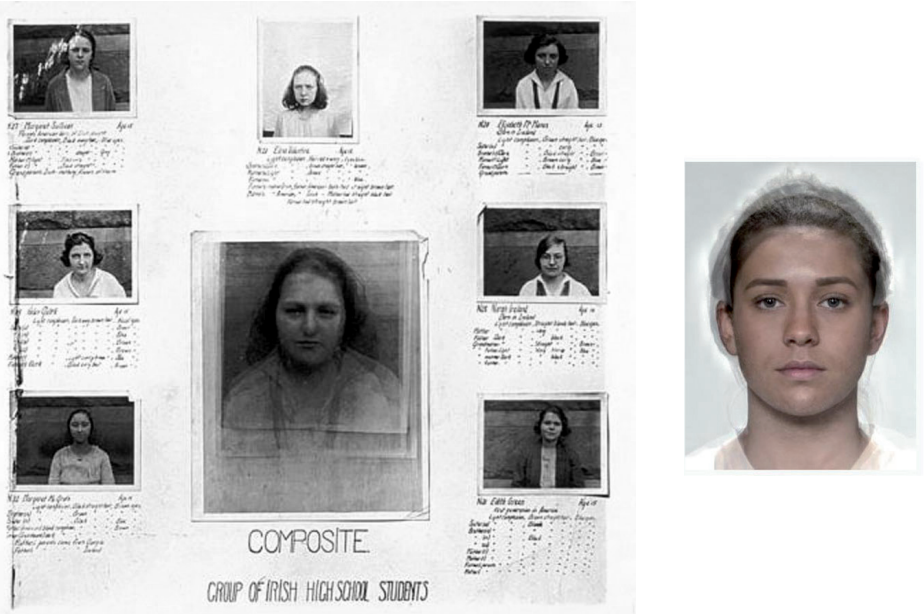

caras de la misma moneda, ambos enfoques han estado presentes a lo largo de la conformación de la 'teoría del tipo' en arquitectura, pero sin duda es esta última la que prevaleció como instrumento para clasificar y distinguir aquellas características permanentes del objeto que lo conectaban con el pasado, y que permitían por tanto establecer un diálogo con la colección de objetos de su misma clase que le habían precedido.

El tipo, así entendido, se constituye como herramienta básica de una arquitectura concebida como lenguaje. Desde la vieja definición de Quatremére de Quincy, preocupada por la distinción entre tipo y modelo -"todo es preciso y dado en el modelo, todo es más o menos vago en el tipo"- (4) hasta su transformación, de la mano de Blondel y Durand, en catálogo disponible para la composición, el debate se centra fundamentalmente en la mayor o menor

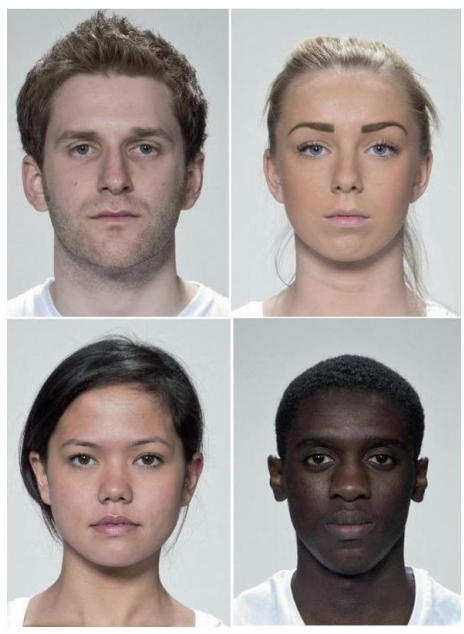

Fig. 1. Galton, Francis: Composite Portrait. Group of Irish Highschool Students. Impresiones fotográficas por exposición sobre el mismo negativo. DNA Learning Center. www.dnalc.org. Fig. 2. Retrato medio (Average Face) obtenido a partir de cuatro fotografías anónimas mediante software desarrollado por el Instituto de Neurociencia y Psicología de la Universidad de Glasgow. Face Research Lab. www.faceresearch.org.

We will therefore distinguish two approaches to the concept of type: the first, linked to normality and the absence of distinctive attributes, which refers to the substrate of the generic. The second, associated with exemplariness and the distinction between sets, which abounds in the specific. Like two sides of the same coin, both approaches have been present throughout the formation of the 'type theory' in architecture, but certainly is the latter which prevailed as a tool to classify and distinguish those permanent features of the object that connected it to the past, and thus allowed to establish a dialogue with the collection of objects of its same class that had preceded it.

The type, so understood, is established as a basic tool for an architecture conceived as language. From the old definition from Quatremere de Quincy, concerned about the distinction between type and model -"all is precise and given in the model, all is more or less vague in the type"- (4) until its transformation, hand Blondel and Durand, in brochures available for composition, the discussion focuses primarily on the degree of fidelity in the interpretation of type as turned into the standard, and the neo-Platonic problem about the type preceding the particular case or vice versa: "Everything must have an antecedent. Nothing, in any genre, comes from nothing". (5) This genealogy culminates, already in the twentieth century, with the centrality granted by Aldo Rossi and his circle (6) to the concept of 'type', even though definitely clarifying the confusion between morphological type and functional type, which had been developed since the publication of Recueil et Parallèle, (7) and that still today lingers in some architecture manuals where buildings are persistently classified depending on their intended use. 
fidelidad en la interpretación del tipo convertido en norma y en el problema neo-platónico de si el tipo precede al caso concreto o viceversa: "para todo es necesario un antecedente. Nada, en ningún género, procede de la nada". (5) Esta genealogía culmina, ya en el siglo $\mathrm{xx}$, con la centralidad otorgada por Aldo Rossi y su círculo (6) al concepto de 'tipo', si bien aclarando definitivamente la confusión entre tipo morfológico y tipo funcional que venía produciéndose desde la publicación de Recueil et Parallèle, (7) y que aún hoy perdura en algunos manuales de arquitectura que insistentemente clasifican los edificios en función del uso al que se destinan.

Pero, a pesar de la tortuosa trayectoria de la noción de 'tipo' a través de la historia, es posible rescatar dos características de gran utilidad para la investigación sobre lo 'neutro' en arquitectura y que hablan de su condición autónoma. Por una parte, su ya mencionada independencia respecto de la función. Así, cuando se afirma que "el tipo define la lógica interna de las formas", no mediante una "traducción formal de los programas" sino como "estructura formal fundamental en arquitectura", lo que se pone de manifiesto es que "puede ser calificado como 'indiferente' frente a su posible adscripción a funciones específicas”. (8)

Por otra parte, su independencia respecto de los estilos. En el marco de la labor pedagógica de la Ėcole Polytechnique, el tipo se desarrolla como algo completamente separado de la superficie exterior, y es precisamente esta diferenciación radical entre objeto en sí y decoración la que convierte al 'tipo' en el artífice de un vaciamiento estilístico, de una producción de "objetos desnudos", (9) que paradójicamente deja el campo abonado para el eclecticismo. (Fig. 3) Sin función ni estilo específico, el tipo podría haber sido el esquema geométrico elemental común a un conjunto de edificios, un neutro capaz de resolver la diferencia en la unidad. Pero la carga simbólica asociada a las formas y a los usos precedentes de éstas no permitió que el discurso prosperara en esta dirección.

But despite the tortuous path of the notion of type through history, it is possible to rescue two useful features for research on the neutral in architecture, which refer to its autonomous status. On the one hand, the aforementioned independence of type from function. Thus, the assertion that "the type preserves and defines the internal logic of forms" not by a "formal translation of programs" but as a "fundamental formal structure in architecture", what is being highlighted is that "it may be qualified as 'indifferent' in front of its potential adscription to specific functions". (8)

On the other hand, the independence of type from style. As part of the pedagogical task of the École Polytechnique, type is developed as something completely separate from the outer surface, and it is precisely this radical distinction between the object itself and its decoration that turns the 'type' into the performer of a stylistic emptying, producing "naked objects", (9) which paradoxically paved the way for eclecticism. (Fig. 3) With no specific function or style, the 'type' could have been the elemental geometric pattern common to a set of buildings, a 'neutral' able to resolve the difference in the unit. But the symbolic weight associated with the forms and their precedent uses did not allow the discourse to thrive in this direction.

Let us now turn to that other approach to the notion of type that focuses its interest on the common-neutral, on that state of affairs in which nothing can yet be qualified by an adjective, although it can receive a name. A sort of architectural genotype awaiting to be activated with the concretion of a phenotype. 


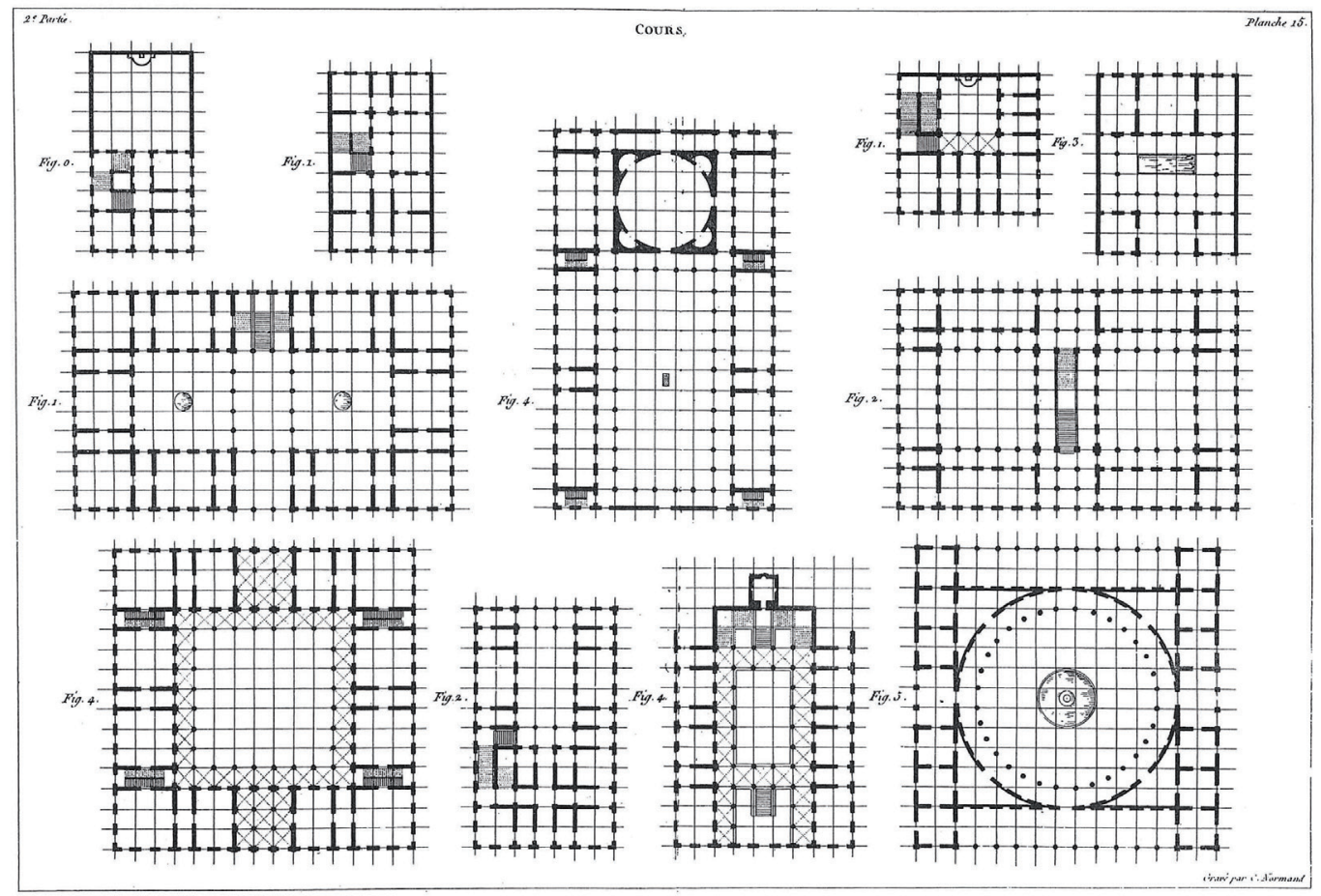

Atendamos ahora a esa otra aproximación a la noción de 'tipo' que concentra su interés en lo neutro-común, en ese estado de cosas en el que nada puede ser todavía adjetivado aunque sí nombrado. Una suerte de Fig. 3. Durand, J.N.L: 'Cours' Planche 15 del vol.II , Précis de Leçons d'architecture donnés à l'Ecole Polytechnique (Paris, 1802-1805). genotipo arquitectónico a la espera de activarse con la concreción de un fenotipo.

The typical. There is an architectural 'type' (in the 'classical' sense of the term) whose raison d'etre is precisely the production of the 'typical'. Just as the production of average portraits demanded congruence between layers in Galton's experiment, gravity imposes the vertical coincidence of loads in the case of overlapping horizontal floors defining the tall building construction. Paradoxically, the 'genuine' product of this architectural operation is the 'generic' typical plan.

This relationship between the 'typical' and the 'neutral' is abundantly exposed in the text of Rem Koolhaas dated 1993 and titled 'Typical Plan'. Fifteen years were required since the publication of Delirious New York for manhatanism rules, purged of surrealist references and narrative intentions, to be finally exposed with the clarity and evidence of the obvious. As if a last and accurate 'hit', etymological sense of the Greek word typus, would have caused the release of all the accidental adhered to his retroactive theory. (Fig. 4)

Described as "zero degree of architecture", the typical plan is able to offer a convincing formulation of the typical because it works with the first fully abstract program: the office building. Strict adaptation to the requirements of this program derives from a denial: the imperative to not interfere. Just as the doctor who swears not to harm the patient, the typical plan's concern is not so much to enable or promote different uses of space as not to obstruct them. Its only function is to "let their occupants exist". (10) "Typical Plan is to the office population what graph pape ris to a mathematical curve. Its neutrality records performance". (11) 
Lo típico. Existe un 'tipo' arquitectónico (en el sentido 'clásico' del término) cuya razón de ser es precisamente la producción de 'lo típico'. Del mismo modo en que la producción de retratos medios exigía la congruencia entre capas en el experimento de Galton, la gravedad impone su demanda de coincidencia vertical de las cargas en el caso de la superposición de suelos horizontales que definen la construcción en altura. Paradójicamente, el producto 'genuino' de esta operación arquitectónica es la 'genérica' planta tipo.

Esta relación entre 'lo típico' y 'lo neutro' se encuentra meridianamente expuesta en el texto de Rem Koolhaas fechado en 1993 y titulado 'Typical Plan'. Fueron necesarios quince años desde la publicación de Delirius New York para que las leyes del manhatanismo, purgadas de referencias surrealistas e intenciones narrativas, fueran finalmente enunciadas con la claridad y la evidencia de lo obvio. Como si un último y certero 'golpe', sentido etimológico del vocablo griego typus, hubiera provocado el desprendimiento de todo lo accidental adherido a su teoría retroactiva. (Fig. 4)

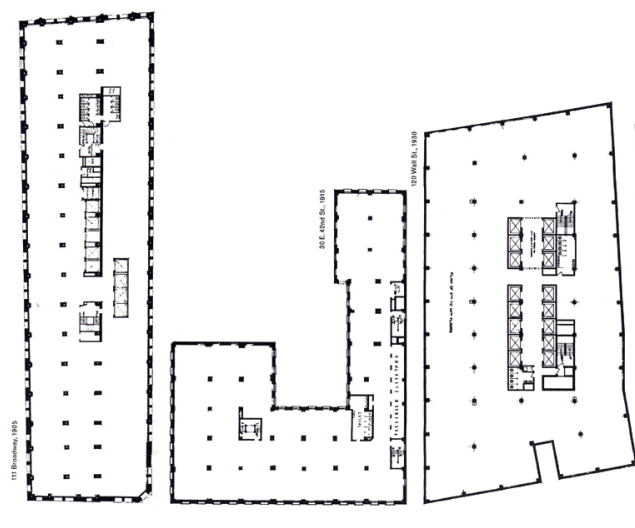

Fig. 4. Secuencia de plantas tipo pertenecientes a la trama neoyorkina tomadas de 'Typical Plan', Koolhaas, Rem: SMLXL, Monacelli Press, Nueva York, 1995.

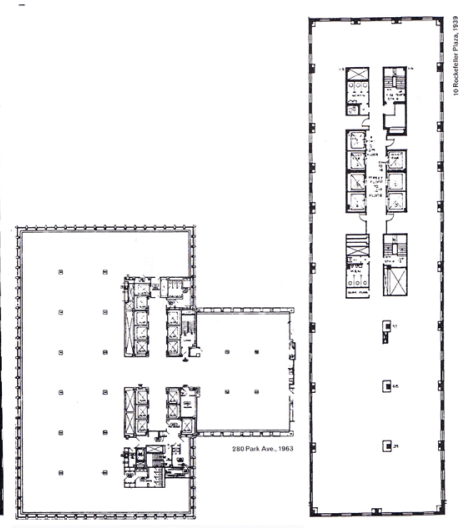

Thus, the understanding of the plan as a neutral background leads to pay more attention to what some have defined as 'typicality', or quality of the typical, whose center of gravity is in the praxis. "The principal difference between 'typology' and 'typicality' is that the former concentrates upon objects, the latter upon human situations". (12) And what definitely makes these situations typical is their repetition frequency. As happens in high rise building, wherein the plan is typical (13) only if it is the umpteenth of a kind.

In front of the notion of 'typological series' linked to the definition of historical types, which can only be modified through the seek for successive refinement, the typical plan proposes the concept of 'variation', pursuing instead the manifestation of some permanence in the internal structure of the object despite being subjected to transformation processes. The endless series of typical plans can not be ranked or ordered by their degree of fidelity to the 'ideal typical plan'. There is not even an archetype for it, since their typical condition is given by its repetition in the object and not outside it.

If we make the 'photofit' of the typical plan, taking some of the specimens presented by Koolhaas and applying to them in turn the overlaying logic of Galton's method, obtaining a typical image of the typical plan it is to be expected. This arithmetic average speaks mainly of a dotted area bounded by any profile. By this way, two qualities of the typical plan are well evidenced which detach it from any similarity to a supposed metaphysical void: on the one hand the unavoidable presence of pillars, responsible for conducting 'real' gravity loads to the soil; on the other, the a-critical assumption of 
Calificada como "grado cero de la arquitectura", la planta tipo es capaz de ofrecer una formulación convincente de lo 'típico' porque trabaja con el primer programa totalmente abstracto: el edificio de oficinas. La estricta adaptación a los requerimientos de este programa procede de una negación: la necesidad imperiosa de no interferir. Como el médico que jura no dañar al enfermo, la planta tipo se ocupa no tanto de posibilitar o promover distintos usos del espacio como de no entorpecerlos. Su única función es "dejar que sus ocupantes existan". (10) "La planta tipo es a la población de oficinistas lo que el papel cuadriculado es a la curva matemática. Su neutralidad registra el acontecimiento". (11)

Es decir, que el entendimiento de la planta como fondo neutro lleva a prestar una mayor atención a lo que algunos han definido como 'tipicalidad', o cualidad de lo típico, cuyo centro de gravedad está en la praxis. "La diferencia principal entre 'tipología' y 'tipicalidad' es que la primera se concentra en los objetos, la otra en las situaciones humanas". (12) Y lo que definitivamente convierte a estas situaciones en típicas es su frecuencia de repetición. Tal y como sucede en la edificación en altura, donde la planta sólo es 'típica' (13) si es la enésima de su clase.

Frente a la noción de 'serie tipológica' vinculada con la definición de los tipos históricos, que sólo pueden modificarse desde la búsqueda de un sucesivo perfeccionamiento, la planta tipo propone el concepto de 'variación', que persigue en cambio la manifestación de cierta permanencia en la estructura interna del objeto a pesar de estar sometido a procesos de transformación. La serie interminable de plantas tipo no puede jerarquizarse ni ordenarse por su mayor o menor fidelidad a la 'planta tipo ideal'. No existe ni siquiera un arquetipo para ella, puesto que su condición típica le viene dada por su repetición en el objeto y no fuera de él.

an inherited urban perimeter from a concrete plot, no matter how singular it is. Quite the contrary, as Koolhaas states himself, if the typical plan embodies some, this is a "metaphysics of slack, that gives an aura of crispiness to even the most severely conflicted geometrical coexistences”. (14) (Fig. 5)

We have seen how functional indifference, the denial of almost any relation to the specific use of the building, is a sine qua non condition of the typical plan. How could then Sullivan's text on the tall office building, containing the more widespread functionalist maximum -form follows function- also contain the genesis of an architecture without attributes? Was not he already appealing to this vagueness when referring to the office-units as "purely arbitrary units of structure"? (15) The subsequent development of the high-rise building, in its ongoing path to hyper-tech open space, would come to prove him right when he asserted the need to "let the problem indeed dissolve". (16)

The Dom-ino Scheme. We can consider that the 'typical plan' precedes the 'free plan' but, lacking the first of a theoretical content expressly stated, is the second that has been responsible for spreading the radical modernity of the scheme that promotes the absolute independence between supporting structure and cladding. The plan, once 'paralyzed' by the identification between the two elements is finally 'liberated', rescued from the involuntary kidnapping imposed by building systems prior to use of reinforced concrete and steel. (17) And if there is an image that embodies this heroic action it is certainly the perspective Le Corbusier's Maison Dom-ino. 
Si realizamos el 'retrato robot' de la planta tipo, tomando algunos de los ejemplares presentados por Koolhaas y aplicándoles a su vez la lógica de la superposición del método de Galton, es esperable obtener una imagen típica de la planta tipo. Esta media aritmética nos habla fundamentalmente de un espacio punteado delimitado por un perfil cualquiera. Se evidencian así dos cualidades de la planta tipo que la alejan de cualquier similitud con un supuesto vacío metafísico: por una parte la presencia irrenunciable de pilares, encargados de conducir las cargas gravitatorias 'reales' hasta el firme; por otra la asunción a-crítica del perímetro heredado de una trama urbana concreta, por singular que éste sea. Muy al contrario, como señala el propio Koolhaas, si la planta tipo encarna alguna, ésta es una "metafísica de la holgura, que es capaz de dotar de una aura de frescor incluso a las coexistencias geométricas más conflictivas". (14) (Fig. 5)

Hemos visto cómo la indiferencia funcional, la negación de casi cualquier relación con el uso específico del edificio, es una condición sine qua non de la planta tipo. ¿Cómo pudo entonces el texto de Sullivan sobre la edificación en altura, que contiene la máxima funcionalista más extendida -form follows function-, contener también la génesis de una arquitectura sin atributos? ¿Acaso no estaba apelando ya a esta indefinición cuando se refería a las unidades-despacho como "unidades de estructura puramente arbitrarias"? (15) El desarrollo posterior de la edificación en altura, en su continuo camino hacia el espacio diáfano hiper-tecnificado vendría a darle la razón cuando afirmaba la necesidad de "dejar simplemente que el problema se disuelva". (16)

El esquema Dom-ino. Podemos considerar que la 'planta tipo' precede a la 'planta libre' pero que, al carecer la primera de un contenido teórico enunciado expresamente, es la segunda la que se ha encargado de difundir la modernidad radical del esquema que promueve la absoluta indepen-
Fig. 5. Superposición de las plantas tipo de la figura 4 a partir de un soporte coincidente y obtención de su posible 'retrato medio'. Dibujo del autor.
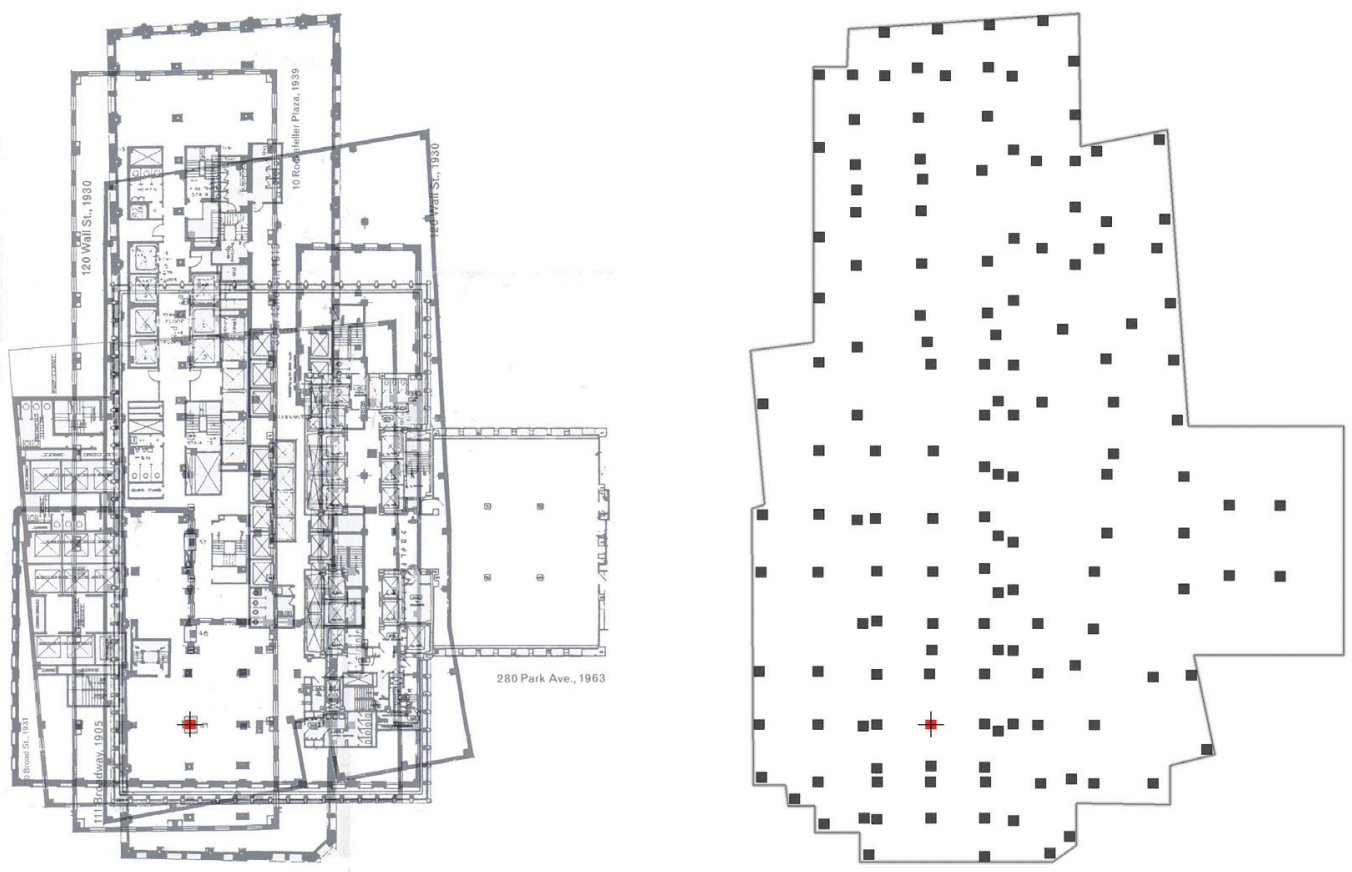
dencia entre estructura portante y cerramientos. La planta antes 'paralizada' por la identificación entre ambos elementos es por fin 'liberada', rescatada del secuestro involuntario que imponían los sistemas constructivos anteriores al empleo del hormigón armado y el acero. (17) Y si hay una imagen que encarna esta acción heroica es sin duda la perspectiva de la Maison Dom-ino de Le Corbusier.

Este 'diagrama espacial canónico' ha sido calificado como 'signo autoreferido', es decir, el primer caso de una arquitectura que contiene en sí misma las claves para su propia interpretación. Esta condición autónoma del objeto, capaz de definir "ciertas condiciones mínimas para cualquier arquitectura" y que permiten distinguirla de la mera geometría, constituye el más temprano indicio de una arquitectura esencialmente moderna. (18) El documento de 1914, generado a partir de una primera idea denominada 'propuesta monolito' basada a su vez en 'el monolito de Mörsch' para la construcción de fábricas (19) -y que Le Corbusier había estudiado en el libro que su amigo Max Dubois había traducido al francés en 1909-, representa un esqueleto estructural completamente desprovisto de particiones y cerramiento, cuyo único elemento estrictamente funcional es la escalera. (Figs. 6, 7)

Desde el territorio neutral suizo, Le Corbusier enuncia así la posibilidad de una reconstrucción casi instantánea de los efectos devastadores de la guerra mediante la trasposición a las unidades domésticas de un método constructivo industrial. Aunque el proyecto Dom-ino no podía materializarse sin los conocimientos técnicos previos acerca del comportamiento de hormigón armado desarrollados por parte de François Hennebique, Auguste Perret, Juste Schneider o el propio Dubuois como colaborador directo, el salto cualitativo que permite calificarlo como 'propuesta revolucionaria’ (20) se deriva de la integración de estos conocimientos téc-
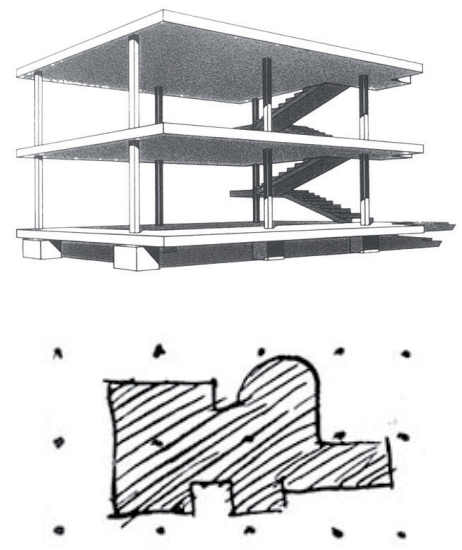

Fig. 6. Prototipo Dom-ino. (1914), perspectiva de la unidad básica. Le Corbusier, Ouevre Complète, vol. I, 1910-29, p.23.

Fig. 7. Fragmento de Les Quatre compositions (1926), correspondiente al tercer tipo de configuración que responde al esquema Dom-ino. Le Corbusier, Ouevre Complète, vol. I, 1910-29, p.189.

This 'canonical space diagram' has been described as 'self-referential sign', that is, the first case of an architecture that contains within itself the keys for its own interpretation. This autonomous status of the object, able to define "certain minimum conditions for any architecture" and which allows distinguishing it from mere geometry, is the earliest evidence of an essentially modern architecture. (18) The 1914 document, generated from a first idea called 'monolith proposal' based in turn on 'Mörsch monolith' for the construction of factories (19) -which Le Corbusier had studied in the book that his friend Max Dubois had translated into French in 1909- represents an entirely devoid of partitions and cladding structural skeleton, whose only strictly functional element is the staircase. (Figs. 6, 7)

From the Swiss neutral territory, Le Corbusier thus states the possibility of a nearly instantaneous reconstruction from the devastating effects of war through the transposition of an industrial building method into domestic units. Although the Domino project could not materialize without prior technical knowledge about the behavior of reinforced concrete -developed by François Hennebique, Auguste Perret, Juste Schneider or Dubuois himself as a direct collaborator- , the qualitative leap that allows to qualify it as a 'revolutionary proposal' (20) is derived from the integration of these technical skills in a completely different vision of architecture and not from the mere application of known solutions solely for the purpose of reducing its cost.

Therefore, it is especially appropriate to talk, as Eleanor Gregh does, not so much about the Dom-ino project but the Domino idea. (21) This idea is none other than the literal translation of the five points elevated to the condition of standardized 
nicos en una visión completamente distinta de la arquitectura y no a su mera aplicación sobre soluciones conocidas con el único fin de abaratar su coste.

Por tanto, es especialmente acertado hablar, como hace Eleanor Gregh, no tanto del proyecto como de la idea Dom-ino. (21) Esta idea no es otra que la traducción literal de los cinco puntos elevados a la condición de 'objeto tipo' estandarizado, listo para su producción en masa. De alguna manera, se puede considerar que la ossature Dom-ino se anticipa a su formulación escrita fechada en 1927 cuando, con ocasión de la exposición de la Weissenhof en Stuttgart, Le Corbusier encuentra por fin el momento de poner en práctica las ideas que venía desarrollando desde hacía más de una década. (22) Para Werner Oechlin, el manuscrito enviado a Alfred Roth contiene todos los elementos de una teoría, en el sentido más clásico de sus objetivos, porque los cinco puntos son aquí presentados como conclusión de un trabajo previo y porque su codificación evidencia la unidad presente ya en los distintos fragmentos y versiones que habían ido apareciendo en publicaciones anteriores como fruto de una marcada preferencia por la revista, el panfleto y el manifiesto. (23)

Precisamente en este texto, que ofrece una definición precisa para cada uno de los cinco puntos, es donde la planta libre queda caracterizada por posibilitar que "todos los pisos sean diferentes entre sí". (24) Pero, ¿no es esto lo contrario de lo que hoy entendemos comúnmente por planta tipo? El estatus de planta tipo sólo se otorga a un plano de arquitectura cuando la idéntica disposición de todas y cada una de sus partes permite omitir la representación de otros niveles. La correspondencia debe ser total, hasta conformar una única entidad repetida exacta y completamente igual a sí misma. Sin duda, Le Corbusier se refiere a esta concepción de la planta tipo cuando afirma en el párrafo final de su artículo en L'Architecture Vivante, en defensa de sus proyectos para la expo-

type-object, ready for its mass production. Somehow, we can consider that the Dom-ino ossature anticipates its written formulation in 1927 when, during the Weissenhof Exhibition in Stuttgart, Le Corbusier finally finds the opportunity to put into practice the ideas that he had been developing for more than a decade. (22) For Werner Oechlin, the manuscript sent to Alfred Roth contains all the elements of a theory, in the most classic sense of its objectives, because the five points are presented here as a conclusion of previous work and because their codification evidences the unity contained in the different fragments and versions that had been appearing in previous publications as a result of a marked preference for the magazine, the pamphlet and the manifesto. (23)

Precisely in this text, which provides an accurate definition for each of the five points, is where free plan is characterized by enabling "every floor to be different from each other". (24) But, is not this the opposite of what we commonly mean by typical plan? The status of typical plan is only given to an architectural plan when the identical arrangement of each and every one of its parts makes it possible to omit the representation of the other levels. Correspondence should be total, up to form a single entity, repeated accurately and fully equal to itself. Undoubtedly, Le Corbusier refers to this conception of typical plan when he says in the final paragraph of his article in L'Architecture Vivante, in defense of their projects for Stuttgart's Exhibition, that "research on housing should not lead to the establishment of a plant-type, but rather to obtain a new structural system, designed so that it can authorize every conceivable combination and thus serve the needs of many categories of individuals". (25) Thereby, the 
sición de Stuttgart, que "la investigación sobre la vivienda no debe conducir a la fijación de una planta-tipo, sino más bien a la obtención de un sistema nuevo de estructura, concebido de forma que pueda autorizar todas las combinaciones imaginables y responder así a las necesidades de muchas categorías de individuos". (25) De este modo, la afirmación inicial sobre la correspondencia entre el concepto de planta tipo según Koolhaas y la noción de 'planta libre' lecorbusierana sólo puede mantenerse si se distancia esta primera de su acepción más común en la práctica profesional.

Le Corbusier detecta también la polisemia de la palabra francesa type que designa coloquialmente a una persona, un individuo, el cual se compone a su vez de un 'tipo físico único' (el cuerpo humano y su rango dimensional) y un 'tipo moral diverso' (con diferentes modos de vida). El primero remite a la estandarización de elementos-tipo, mientras que el segundo conduce a la agrupación en categorías. De esta forma, tomando al hombre mismo como referencia, resuelve el equilibrio entre las dos vertientes complementarias de lo 'típico': lo común y lo singular.

Cuando Le Corbusier describe la idea Dom-ino introduce un concepto especialmente relevante para la comprensión de lo neutro: "este sistema de estructura constituye una reserva arquitectónica", (26) dice. E insiste sobre la palabra 'reserva' como algo que se encuentra en un estado latente, que existe con independencia del destino final del edificio. Una suerte de información registrada en su $\mathrm{ADN}$ que permite múltiples configuraciones.

De esta forma, la distinción entre estructura y particiones provoca un desfase temporal, una descripción de dos tiempos consecutivos cuya distancia irá ampliándose desde la propia secuencia de ejecución hacia una concepción más a largo plazo de la vida del edificio. La idea Dom-ino puede verse así como el germen de una arquitectura definida como potencia, es decir, como

initial statement of the correspondence between the concept of typical plan according to Koolhaas and the notion of free plan from Le Corbusier, can only be maintained if the first is pushed at a certain distance from its most common usage in professional practice.

Le Corbusier also detects the polysemy of the French word type, that colloquially refers to a person, an individual, which in turn consists of a 'single physical type' (the human body and its dimensional range) and a 'varying moral type' (with different lifestyles). The first refers to the standardization of the type-element, while the second leads to grouping into categories. Thus, taking as reference the man himself, he solves the balance between the two complementary sides of the 'typical': the common and the unique.

When Le Corbusier describes the Dom-ino idea he introduces an especially relevant concept for the understanding of the neutral: "this structural system is an architectural reserve", (26) he says. And he insists on the word 'reserve' as something that is in a dormant state, which exists regardless of the final destination of the building. A kind of registered information on its DNA that allows multiple configurations.

In this way the distinction between structure and partitions causes a time unfolding, a description of two consecutive times whose distance will expand from the execution sequence itself to a longer-term design conception of the building's life. The Dom-ino idea can be then seen as the seed of an architecture defined as potency, that is, as the set of situations 
el conjunto de situaciones que pueden llegar a darse gracias a un mínimo de información material que permanece estable y que se considera 'neutro' respecto de ellas. Un estado de energía residual o 'en reserva'.

Es muy significativo que en este proceso de reducción esencial, tanto Le Corbusier como Mies, llegaran en su madurez a una definición arquitectónica prácticamente idéntica de los dos tipos básicos de la modernidad -el bloque laminar residencial y el rascacielos de oficinas-, si bien "evitaron sistemáticamente explorar las implicaciones de esta progresiva identificación". (27) Tal vez, cabría preguntarse por qué la ansiada 'libertad' conquistada para la planta por el primero se transformó en radical 'neutralidad' intencionada en el segundo. (28)

La teoría de soportes. A las puertas de la segunda mitad del siglo xx, el desarrollo de los sistemas industrializados de prefabricación, de componentes o de unidades completas, impulsado nuevamente por un conflicto bélico, colocó a la arquitectura en una situación muy cercana a la mera edificación. Especialmente en el terreno residencial, lo normal pasó a ser normativo, en una gigante operación de 'neutralización', entendida como anulación de la diferencia. Así, la actividad principal de reconstrucción de las ciudades europeas, concentrada en manos de la industria y bajo una estricta supervisión gubernamental, se entregó a la definición de una arquitectura sin atributos por exigencias de un guión marcado por la restricción tipológica. (29) Esta situación post-bélica, en la que la vivienda constituye un objetivo definido casi exclusivamente en términos cuantitativos, es lo que John Habraken definió en 1961 como el "problema del alojamiento de masas". (30)

Su aproximación al problema argumenta que la uniformidad con la que se pretende dar solución al 'cliente medio' no es una exigencia impuesta por motivos técnicos sino porque se ha desatendido completamente al individuo. (31) Para Habraken, el concepto de tipo es básicamente sistémico, (32)

that may come to be by a minimum of material information that remains stable and which is considered 'neutral' regarding them. A state of residual or in 'reserve' energy.

It is significant that in this process of essential reduction, both Le Corbusier and Mies arrived at maturity to an almost identical architectural definition of the two basic building types of modernity -the residential linear block and the highrise office building- although they "systematically avoided to explore the implications of this progressive identification". (27) Maybe, one might ask why the desired 'freedom' conquered for the plan by the first was transformed into radical intended 'neutrality' by the second. (28)

Supports Theory. On the doorstep of the second half of the twentieth century, the development of industrialized prefabrication systems, components or complete units, driven again by a war conflict, placed architecture in a situation very close to mere building. Especially in the residential field, the normal became norm, within a giant neutralization operation understood as exclusion of difference.

Thus, the main activity of reconstruction of European cities, concentrated in the hands of industry and under strict government supervision, devoted itself to the definition of an architecture without attributes under the requirements of a script marked by typological restriction. (29) This post-war situation, in which the housing is almost exclusively a goal established in quantitative terms, is what John Habraken defined in 1961 as the 'problem of mass housing'. (30) 
es decir, que la imagen compartida de un tipo no es una 'plantilla' que deba ser aplicada, sino una familia de configuraciones en la que "el ejemplo más primitivo contiene el germen del más elaborado". (33) En este sentido, comprender un tipo no es un ejercicio que persiga la definición de un prototipo definitivo, porque cada variación formulada es válida sólo en su contexto. El error implícito en la elección de un 'tipo óptimo', susceptible de ser repetido un número suficientemente rentable de veces, está en la raíz del cambio de modelo propuesto por su Teoría de Soportes.

Un soporte es una construcción que, no siendo ella misma vivienda, ni propiamente un edificio, es capaz de sostener las viviendas sobre el terreno. Desempeña el papel del terreno mismo. Es una construcción que provee de terreno en alto y que es permanente, como calles. Y sobre todo, como cualidad fundamental, permite que esas viviendas sean construidas, mo-
Fig. 8. Sistema de zonas y márgenes.

Fig. 9. Comprobación mediante variaciones de la capacidad de las zonas para albergar dormitorios o baños. Habraken, J.N: El diseño de soportes, Barcelona, GG, 2000.

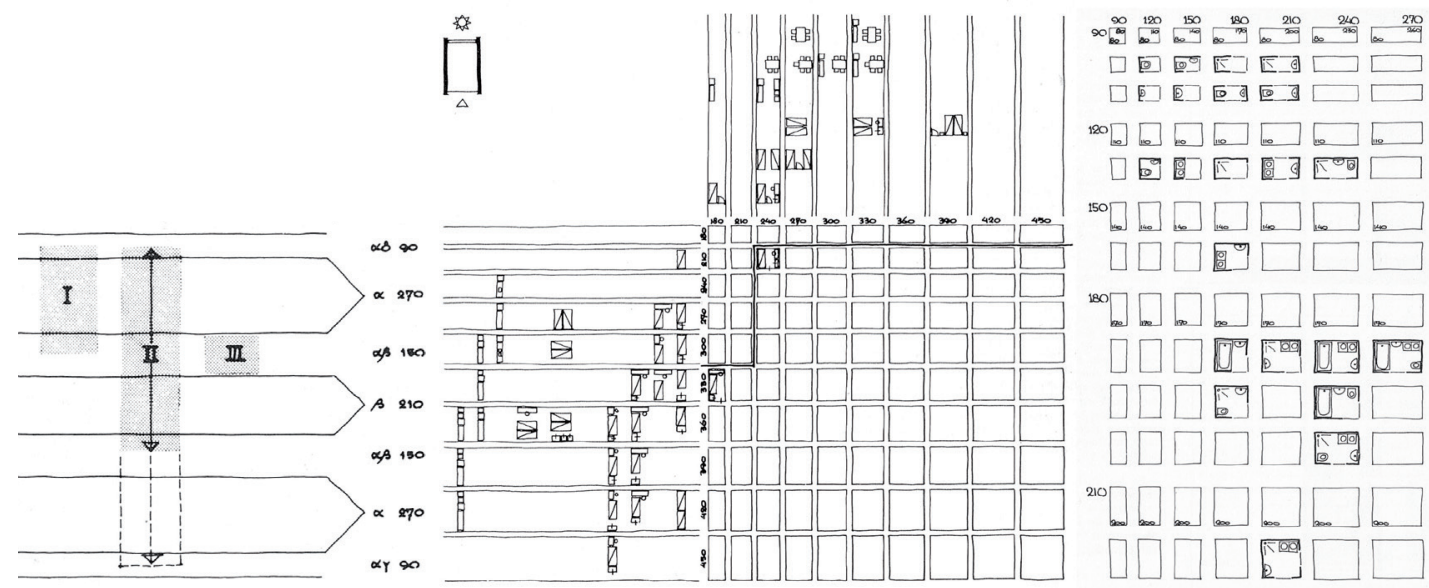

His approach argues that the uniformity with which it is intended to solve the 'average customer' is not a requirement imposed for technical reasons but because it has completely neglected the individual. (31) To Habraken, the concept of type is basically systemic, (32) ie, the shared image of a type is not a 'template' that should be applied, but a family of configurations in which "the earliest example contains the germ of the more elaborated". (33) In this sense, understanding a type is not an exercise that seeks the definition of a final prototype, because every proposed variation is valid only in its context. The implicit error in the choice of an 'optimal type', capable of being repeated a sufficiently profitable number of times, is at the root of the change of model proposed by Supports Theory.

A support is a construction that, without being itself neither dwelling nor strictly a building, is capable of holding dwellings over the plot. It plays the role of land itself. It is a construction that provides land in the air and which is permanent, such as streets. And, above all, as a fundamental quality, it allows these homes to be built, demolished or modified independently of each other by 'infill packages'. In the 'design of supports' there is no final plan of the house. From a support it can not be evaluated nothing more than its capacity by verifying all possible 'variations'. There is no need to 'decide' on the function but to 'assess' the form which in this case precedes it. (34) (Figs. 8, 9)

Taking the 'linear block' with dual orientation as a basic type for the construction of housing, a support defines a set of 'zones' and 'margins' with a certain capacity. This is ultimately a system of areas of probability with a certain tolerance. 
dificadas o demolidas independientemente las unas de las otras mediante 'paquetes de relleno (infill packages)'. En el 'diseño de soportes' no existe una planta final de la vivienda. De un soporte no se puede evaluar más que su capacidad mediante la comprobación de todas las 'variaciones' posibles. No es necesario 'decidir' sobre la función sino 'evaluar' la forma que en este caso la precede. (34) (Figs. 8, 9)

Tomando el 'bloque laminar' con doble orientación como tipo básico para la construcción de viviendas, un soporte define un conjunto de 'zonas' y 'márgenes' con una determinada capacidad. Se trata en definitiva de un sistema de zonas de probabilidad con una cierta tolerancia. Pero la cuestión fundamental en la distinción entre soporte y relleno no es ni la forma específica de ninguno de ellos, ni la división temporal en dos fases inherente al sistema, sino los 'niveles de control' que el individuo, la comunidad y los entes públicos tienen sobre cada parte. Lo verdaderamente nuevo del planteamiento no es tanto la 'flexibilidad' que se alcanza en cuanto a la disposición y a la posibilidad de adaptación de las viviendas, sino la traducción de la jerarquía en la toma de decisiones a un sistema de elementos físicos netamente distinguibles los unos de los otros por el agente que tiene la capacidad y el deber de gestionarlos. (35) En estos términos debe entenderse la afirmación de Habraken, para quien la Teoría de Soportes "alentaba el desarrollo de una nueva sociedad". (36)

Por supuesto, el impacto de la prefabricación en el proceso descrito era determinante y, a menudo, se ha visto la experiencia del SAR (Stichting Architecten Research) fundado en 1965 con el propio Habraken como director, como una organización de tecnócratas al servicio de la industria. Sin embargo, el planteamiento contiene todos los ingredientes de una auténtica teoría, y como tal puede ser analizada y puesta en relación con las experiencias precedentes y coetáneas.

But the fundamental issue in the distinction between support and infill is not the specific form of any of them, nor the temporal division into two phases inherent to the system, but the 'levels of control' which the individual, the community and public authorities have over each part. The truly new approach is not so much the 'flexibility' that is reached regarding the disposition and the possibility of adaptation of housing units, but the translation of hierarchy in decision making to a system of physical elements clearly distinguishable from each other by the agent who has the ability and the duty to manage them. (35) It is in these terms that Habraken's claims should be understood, for whom Supports Theory “encouraged the development of a new society". (36)

Of course, the impact of prefabrication in the process described was critical and the experience of the SAR (Stichting Architecten Research) founded in 1965 with Habraken himself as director, has often been seen as an organization of technocrats in the service of industry. However, the approach has all the ingredients of an authentic theory, and as such can be analyzed and set in relation with the preceding and coetaneous experiences.

One might think that a 'support' is very similar to what Le Corbusier sought to conceive with the Dom-ino idea. At the end of the day, it is all about a basic scheme that allows multiple configurations. Understood the Dom-ino idea as 'design method', parentage with the Supports Theory seems evident. (37) However, Habraken insisted on pointing two important differences. (Figs. 10, 11) 
Podría pensarse que un 'soporte' es algo muy parecido a lo que Le Corbusier pretendía concebir con la idea Dom-ino. Al fin y al cabo, se trata de un esquema básico que permite múltiples configuraciones. Entendida la idea Dom-ino como 'método de diseño', el parentesco con la Teoría de Soportes resulta evidente. (37) No obstante, el propio Habraken insistía en señalar dos diferencias importantes. (Figs. 10, 11)

Por una parte, el carácter infraestructural de un soporte. No se trata de un edificio inacabado sino de uno completo en sí mismo. Y aquí Habraken traza la analogía con el puente o la autopista y los coches que circulan por ella. Dos entidades independientes, cada una de las cuales asume la presencia de la otra. (38) Por otra parte, la posibilidad de ser muy específico en las sugerencias que el propio soporte contiene acerca de su ocupación. Es decir, una condición más 'generativa' que 'general'. Y en este punto Habraken se distancia específicamente de la idea de Le Corbusier. Preguntado en una de las reuniones del SAR, responde: "Entendido como un edificio, un soporte no es un esqueleto neutral como el Dom-ino: es Arquitectura". (39) Es decir, lo neutro es interpretado aquí como un rasgo anti-arquitectónico, una muerte fatal y definitiva de la arquitectura. Si todo se reduce a establecer la distancia entre los pilares y la relación de estos con el perímetro, lo que se ofrece es una libertad total al ocupante que dispone de infinitas posibilidades de organización, pero que no dispone de las herramientas necesarias para aprovecharlas. Sin puntos de partida ni formación específica, el usuario final está desasistido en el proceso, y esto es precisamente lo que un soporte debe evitar. (40)

También se encargó Habraken de distanciarse de la práctica habitual en los edificios de oficinas, donde, a pesar de que el edificio base y el interior se diseñan y ejecutan como dos entidades independientes, esta práctica responde a intereses comerciales bien distintos de los que proponía la Teoría de Soportes.
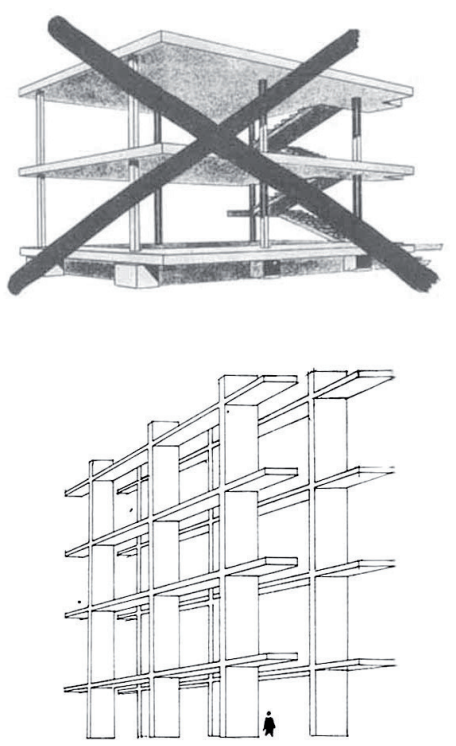

Fig. 10. La imagen icónica de la Maison Domino tachada con una cruz fue empleada por Habraken para ilustrar lo que un soporte no era. Bosma, K. et al. 2000.

Fig. 11. Uno de los escasos dibujos generados para ilustrar lo que un soporte podría ser. Bosma, K. et al. 2000.

On the one hand, the infrastructural character of a support. It is not an unfinished building but one complete in itself. And here Habraken traces the analogy with the bridge or the highway and cars driving along it. Two independent entities, each of which assumes the presence of the other. (38) On the other hand, the possibility to be very specific in the suggestions that the support itself contains about its occupation. That is, more a 'generative' than a 'general' condition. And at this point Habraken distances himself specifically from Le Corbusier's idea. Inquired at one of SAR's meetings, he replied: "Understood as a building, a support is not a neutral skeleton as the Dom-ino: it is architecture". (39) So, the neutral is interpreted here as an anti-architectural feature, a fatal and final death of architecture. If it all comes down to set the distance between pillars and the relationship of these to the perimeter, what is being offered is total freedom to the occupant, that has infinite possibilities of organization but that does not have the necessary tools to take advantage of them. Without starting points and specific training, the end user is unassisted in the process, and this is precisely what a support should avoid. (40)

Habraken also tried to distance himself from the common practice in office buildings, where, despite the base building and the interior are designed and implemented as two separate entities, this practice responds to commercial interests very different from those proposed by Supports Theory. "What we proposed was to produce a building block without floor plans. If you eliminate the floor plan you actually reverse the process. The idea that a building is a multiplication of a floor plan is, of course, absurd! (41) Thus, despite Habraken's rejection to identify his theory with the work of Le Corbusier, the abolition of the typical plan was a goal shared by both. 
"Lo que pretendíamos hacer es un edificio sin plantas tipo. Si eliminas la planta tipo, inviertes radicalmente el proceso. [...] La idea de que un edificio es la multiplicación de una planta tipo es, por supuesto, absurda!" (41) Así, a pesar del rechazo de Habraken a identificar su teoría con el trabajo de Le Corbusier, la abolición de la planta tipo era un objetivo compartido por ambos.

Resulta por tanto evidente que las ideas desarrolladas por el SAR tienen su germen en una línea de pensamiento incubada ya en la experiencia de la construcción en altura americana, inaugurada oficialmente en Europa por Le Corbusier en 1914 y desarrollada posteriormente en su Plan Obus o en las Unité d'Habitation, y que se encuentra completamente conectada con la reflexión holandesa de los años sesenta en torno a la flexibilidad y la polivalencia. Pero lo que sin duda no puede negarse, y esta es la razón por la que es relevante para el estudio de lo 'neutro' en arquitectura, es que la de Habraken es la formulación más abstracta de todos los ejemplos mencionados.

Su reticencia a ofrecer una imagen concreta de lo que debería ser un soporte le permitió no discutir el concepto en términos estéticos, y por lo tanto resulta imposible deducir la forma exacta de un soporte como conclusión de ninguno de sus textos o documentos. Habraken nunca diseñó un soporte y su libro de 1961 no contiene ni una sola ilustración. Lejos de ser una incapacidad, esta limitación fue fruto de un acto consciente, una decisión estratégica que pretendía proteger a la Teoría de Soportes de una identificación personal, que sin duda la hubiera debilitado. Pero lo cierto es que, a la luz de lo que constituye hoy la práctica de la edificación residencial, es inevitable admitir que el objetivo no fue alcanzado. La neutralidad implícita en su renuncia a producir resultados individuales con el tiempo demostró ser una debilidad en la comunicación de sus ideas, y así lo admitió tras la disolución del SAR cuando afirmaba: "Subestimé la importancia de la traducción de mi trabajo en arquitectura. Es algo que simplemente dimos por supuesto". (42)

It is therefore evident that the ideas developed by the SAR have their genesis in a line of thought already incubated in high-rise building experience in America, officially launched in Europe by Le Corbusier in 1914 and subsequently developed in his Obus Plan or the various Unité d'Habitation, and which is fully connected to the Dutch reflection of the 60's around flexibility and polyvalence. But what certainly can not be denied, and this is the reason why it is relevant to the study of the 'neutral' in architecture, is that Habraken's is the most abstract formulation of all the examples cited.

His reluctance to provide a concrete picture of what a support should be allowed him not to discuss the concept in aesthetic terms, and therefore it is impossible to deduce the exact form of a support as a conclusion of any of his texts or documents. Habraken never designed a support and his 1961 book contains not a single illustration. Far from being a failure, this limitation was the result of a conscious act, a strategic decision intended to protect Supports Theory from any personal identification, which certainly would have weakened it. But the truth is that, in the light of what is today the practice of residential building, it is inevitable to admit that the goal was not achieved. The implicit neutrality in his renounce to produce individual results proved, over time, to be a weakness in communicating his ideas, and so he admitted it when after SAR's dissolution he affirmed: "I underestimated the importance of translating my work into architecture. That's something that we simply took for granted”. (42) 


\section{NOTAS}

1. KOOLHAAS, Rem. 'Typical Plan'. En $S, M, L, X L$. Nueva York: Monacelli Press, 1995. 338 p.

2. Francis Galton (1822-1911). Antropólogo, geógrafo, meteorólogo y estadístico inglés que descubrió entre otras cosas la singularidad de las huellas dactilares para cada individuo, introdujo conceptos estadísticos como la correlación, la regresión a la media o la distribución normal, pero es sobre todo conocido por su teoría de la eugenesia o selección artificial. En 1901 cofundó la revista Biometrika que continúa editándose.

3. La definición de 'arquetipo' está tomada de: FERRATER MORA, José. Diccionario de Filosofía. [Ed. Consultada: Ariel. Barcelona, 2009. Tomo IV, 3512 p.]. En cambio la definición de 'prototipo' remite al uso de este término en el campo de la industrialización.

4. QUATREMÈRE DE QUINCY, Antoine. Entrada 'type' de la Encyclopédie Méthodique d'Architecture, vol.III. Paris, 1788. [Ed. Consultada : Paris, 1825. pp. 543-545].

\section{Ibídem.}

6. Nos referimos a la difusión en los años cincuenta desde las páginas de Casabella-Continuità del trabajo teórico de Saverio Muratori y Ernesto Rogers (director 1953-64) y de Giulio Carlo Argan, Aldo Rossi y Carlo Aymonino en las décadas posteriores. 7. DURAND, Jean-Nicolas-Louis. Recueil et parallèle des édifices de tout genre, anciens et modernes, remarquables par leur beauté, par leur grandeur ou par leur singularité, et dessinés sur une même échelle. Paris: A L'École Polytechnique, chez l'auteur, 1800.

8. MONEO, Rafael. 'On Typology' Oppositions. n. 13, (Summer, 1978). pp. 22-45. [Versión en castellano consultada: 'Sobre la noción de tipo' en Rafael Moneo: 1967-2004. Madrid: Croquis Editorial, 2004].

9. VIDLER, Anthony. 'The Idea of Type: The Transformation of the Academic Ideal, 1950-1830' en Oppositions. n. 8, (Spring, 1977). pp. 95-115. Recogido en: HAYS, K. Michael. Oppositions Reader: Selected Readings from a Journal for Ideas and Criticism in Architecture, 1973-1984, New York: Princeton Architectural Press, 1998.

10. KOOLHAAS, Rem. Op. cit. 337 p.

11. Ibídem. 341 p.

12. CARL, Peter. 'Type, Field, Culture, Praxis'. Architectural Design. vol. 81, n.1. 2011. El artículo propone la sustitución de los términos 'type' por 'typical' y 'typology' por 'typicality' para desplazar el debate sobre el tipo desde lo que define como campo conceptual ('Conceptual Field') hacia la especificidad de lo que designa como topografía de la praxis ('Topography of Paxis').

13. La diferenciación entre los términos 'tipo' y 'típico' que estamos haciendo con respecto a la planta no se dan en la lengua inglesa, donde se habla sólo de 'Typical Plan' y no de 'Type Plan'. A pesar de todo, mantenemos esta dialéctica de forma intencionada, del mismo modo que entendemos que el propio Koolhaas elige la expresión 'Typical Plan' y no la más habitual 'Typical Floor', valorando la polisemia de 'plan' (planta y plan) frente a 'floor' (piso, nivel).

14. KOOLHAAS, Rem. Op. cit. 340 p.

15. SULLIVAN, Louis H. 'The Tall Office Building Artistically Considered'. Lippincott's Monthly Magazine. n.339. Philadelphia: J.B. Lippincott Co, 1896. pp. 403-409.

16. Ibídem. "Let the problem indeed dissolve".

17. "Je vous rappelle ce 'plan paralysé' de la maison de pierre et ceci à quoi nous sommes arrivés avec la maison de fer ou

\section{NOTES}

1. KOOLHAAS, Rem. 'Typical Plan' in $S, M, L, X L$. New York: Monacelli Press, 1995. 338 p.

2. Francis Galton (1822-1911). Anthropologist, geographer, meteorologist and statistical Englishman who discovered, among other things, the uniqueness of fingerprints for each individual, introduced statistical concepts such as correlation, regression toward the mean or normal distribution, but who is mostly known for his theory of eugenics or artificial selection. In 1901 he co-founded the journal Biometrika, which continues to be published.

3. The definition for 'archetype' is taken from: FERRATER MORA, José. Diccionario de Filosofía. [Consulted Ed.: Ariel. Barcelona, 2009. Tomo IV, pp.3512]. Instead, the definition for prototype refers to the use of this term within the industrialization field.

4. QUATREMÈRE DE QUINCY, Antoine. Entry 'type' from the Encyclopédie Méthodique d'Architecture, vol.III. Paris. 1788. [Consulted ed.: Paris, 1825. pp. 543-545].

5. Ibídem.

6. We refer here to the dissemination from Casabella-Continuità pages during the 50's of the theoretical work of Severino Muratori and Ernesto Rogers (director 1953-64) and Giulio Carlo Argan, Aldo Rossi and Carlo Aymnonino during the subsequent decades. 7. DURAND, Jean-Nicolas-Louis. Recueil et parallèle des édifices de tout genre, anciens et modernes, remarquables par leur beauté, par leur grandeur ou par leur singularité, et dessinés sur une même échelle. Paris: A l'École polytechnique, chez l'auteur, 1800.

8. MONEO, Rafael. 'On Typology'. Oppositions. n. 13, (Summer, 1978). pp. 22-45. [Consulted version in spanish: 'Sobre la noción de tipo' in Rafael Moneo: 1967-2004. Madrid: Croquis Editorial, 2004].

9. VIDLER, Anthony. 'The Idea of Type: The Transformation of the Academic Ideal, 1950-1830' in Oppositions. n. 8, ) (Spring, 1977). pp. 95-115. Also compiled in: HAYS, K. Michael. Oppositions Reader: Selected Readings from a Journal for Ideas and Criticism in Architecture, 1973-1984. New York: Princeton Architectural Press, 1998. pp.438-459.

10. KOOLHAAS, Rem. Op. cit. 337 p.

11. Ibídem. $341 \mathrm{p}$.

12. CARL, Peter. 'Type, Field, Culture, Praxis' in Architectural Design. vol. 81, $\mathrm{n}^{\circ} 1.2011$. The article proposes the replacement of the term 'type' for 'typical' and 'typology' for 'typicality', in order to shift the debate on the type from what he defines as 'conceptual field' to the specificity of what he designates as 'topography of praxis'.

13. The distinction between the terms 'type' and 'typical' we're doing with respect to the plant do not exist in the English language, which speaks only of 'Typical Plan' rather than 'Type Plan'. Nevertheless, we maintain this dialectic intentionally, just as we understand that Koolhaas himself chooses the term 'Typical Plan' and not the usual 'Typical Floor', assessing the polysemy of 'plan' (layout and programme) vs. 'floor' (level). 14. KOOLHAAS, Rem. Op. cit. 340 p.

15. SULLIVAN, Louis H. 'The Tall Office Building Artistically Considered'. Lippincott's Monthly Magazine. n. 339. Philadelphia: J.B. Lippincott Co, 1896. pp. 403-409.

16. Ibídem. "Let the problem indeed dissolve".

17. "Je vous rappelle ce 'plan paralysé' de la maison de pierre et ceci à quoi nous sommes arrivés avec la maison de fer ou de ciment armé [...]". LE CORBUSIER. Précisions sur un état présent 
de ciment armé [...]". LE CORBUSIER. Précisions sur un état présent de l'architecture et de l'urbanisme, Paris: G. Crès, 1930. [Ed. en castellano: Precisiones respecto a un estado actual de la arquitectura y del urbanismo. Ed. Apóstrofe, 1999].

18. EISENMAN, Peter. 'Aspects of Modernism: Maison Dom-ino and the Self-Referential Sign'. Oppositions. n. 15/16, (Winter/ Spring, 1979). pp.118-128. Recogido también en: HAYS, K. Michael. Oppositions Reader: Selected Readings from a Journal for Ideas and Criticism in Architecture, 1973-1984. Nueva York: Princeton Architectural Press, 1998.

19. La genealogía del proyecto Dom-ino se encuentra detallada en: CORRES, Elena. 'Proyecto Dom-ino: el sistema estructural' en Massilia, 2002: anuario de estudios lecorbusierianos. Barcelona: Edición Fundación Caja de Arquitectos, 2002. pp. 4-38. El texto publicado es un capítulo de su tesis doctoral titulada $E l$ Proyecto Dom-ino y leída en la Universidad de Sevilla en 2001, en el que se abordan diversas hipótesis para explicar el comportamiento estructural de las soluciones constructivas del proyecto Dom-ino, así como sus posibilidades reales de ejecución.

20. Para Du Boix, era una "idea simplista, que yo hubiera tenido sin profundizar, pero que con su entusiasmo juvenil, Jeanneret había decidido que sería una revolución”. Carta de Du Boix a Eleanor Gregh del 16 de Agosto de 1978, recogida en: GREGH, Eleanor. 'The Dom-ino Idea'. Oppositions. n. 15/16, (Winter/ Spring, 1979). pp. 60-87.

21. Ibídem. A pesar de la extensa bibliografía sobre el tema, éste sigue siendo un texto de obligada referencia en el que profundiza detalladamente en el contexto biográfico e ideológico de la gestación del proyecto Dom-ino, entre los años 1907-1916.

22. “Stuttgart c'est l'ocassion, enf in!” LE CORBUSIER. Ouvre complète. $45 \mathrm{p}$.

23. OECHLIN, Werner. 'Les Cinq Points d'une Architecture Nouvelle' en Assemblage. n. 4, oct. 1987. The MIT Press, pp. 83-93. 24. "LE PLAN LIBRE.- Les pilotis se poursuivent jusqu'a la toiture, portant leurs planchers. Ils ne gênent aucunement la disposition des cloisons verticales qui sont différents à chaque étage. Il n'y a plus de murs portants, il y a des membranes légères et tous les étages son différents les uns des autres". (Subrayado en el original). El texto completo está reproducido en OECHLIN, W. Op. cit.

25. LE CORBUSIER. 'La signification de la cité-jardin du Weissenhof à Stuttgart'. L'Architecture Vivante. Printemps \& Été, 1928. Éditions Albert Morancé. pp. 9-15.

26. Ibídem. 11 p. "Ce système de structure constitue donc des réserves architecturales. J'insiste sur le mot 'réserve' qui signifie qu'un esprit inventif peut appliquer ces réserves à la construction d'une maison comme à celle d'un palais. Et alors ces maisons seront-elles des maison-types, c'est-à-dire de quel type seront-elles ?" (Énfasis en el original).

27. ÁBALOS, Iñaki; HERREROS, J. 'Hibridos' en Arquitectura COAM. n. 290, (enero, 1992). pp. 54-80.

28. "Pretendo que mis edificios sean marcos neutros donde los hombres y las obras de arte puedan llevar su propia vida. Para conseguirlo se necesita una postura respetuosa frente a los objetos". Ludwig Mies van der Rohe en conversación con Christian Norberg-Schulz . 'Una conversación con Mies van der Rohe' en NEUMEYER, Fritz. Mies van der Rohe: la palabra sin artificio: reflexiones sobre arquitectura, 19221968. Madrid: El Croquis, 1995. 516 p. [Ed. original: The Artless Word: Mies Van De Rohe on the Building Art. The MIT Press, 1991]. de l'architecture et de l'urbanisme. Paris: G. Crès, 1930. [Spanish Ed.: Precisiones respecto a un estado actual de la arquitectura y del urbanismo. Ed. Apóstrofe, 1999].

18. EISENMAN, Peter. 'Aspects of Modernism: Maison Dom-ino and the Self-Referential Sign'. Oppositions. n. 15/16, (Winter/ Spring, 1979). pp.118-128. Also compiled in: HAYS, K. Michael. Oppositions Reader: Selected Readings from a Journal for Ideas and Criticism in Architecture, 1973-1984. New York: Princeton Architectural Press, 1998.]

19. The genealogy of the Dom-ino Project is detailed in: CORRES, Elena. 'Proyecto Dom-ino: el sistema estructural' in Massilia, 2002: anuario de estudios lecorbusierianos. Barcelona: Edición Fundación Caja de Arquitectos, 2002. pp.4-38. The published text is a chapter of her doctoral thesis entitled $E l$ Proyecto Dom-ino and defended at Sevilla University in 2001, in which several hipótesis are presented to explain teh estructural behaviour of the constructive solutions at the Dom-ino Project, as well as their real chances to be executed.

20. For Du Boix, it was "a simplistic idea, one which I would have had without deepening, but which with his youthful enthusiasm, Jeanneret had decided it was going to become a revolution". Letter from Du Boix a Eleanor Gregh dated august 16th 1978, and complied in: GREGH, Eleanor. 'The Dom-ino Idea'. Oppositions. n. 15/16, (Winter/Spring, 1979). pp. 60-87. 21. Ibídem. In spite of the extensive bibliography on the topic, this continues to be a mandatory referential text, which deepens in detail into the biographical and ideological context of the Dom-ino project gestation, between the years 1907-1916. 22. "Stuttgart c'est l'ocassion, enfin!” LE CORBUSIER. Ouvre complète. $45 \mathrm{p}$.

23. OECHLIN, Werner. 'Les Cinq Points d'une Architecture Nouvelle' in Assemblage. n.4, oct. 1987. The MIT Press. pp. 83-93 24. “LE PLAN LIBRE.- Les pilotis se poursuivent jusqu'a la toiture, portant leurs planchers. Ils ne gênent aucunement la disposition des cloisons verticales qui sont différents à chaque étage. Il n'y a plus de murs portants, il y a des membranes légères et tous les étages son différents les uns des autres". (Underlined in the original). Full text is reprinted in OECHLIN, W. Op. cit.

25. LE CORBUSIER, 'La signification de la cité-jardin du Weissenhof à Stuttgart'. L’Architecture Vivante. Printemps \& Été, 1928. Éditions Albert Morancé. pp. 9-15.

26. Ibídem. 11 p. "Ce système de structure constitue donc des réserves architecturales. J'insiste sur le mot 'réserve' qui signifie qu'un esprit inventif peut appliquer ces réserves à la construction d'une maison comme à celle d'un palais. Et alors ces maisons seront-elles des maison-types, c'est-à-dire de quel type seront-elles ?" (Emphasis in the original).

27. ÁBALOS, Iñaki; HERREROS, J. 'Hibridos' in Arquitectura COAM. n. 290, (enero, 1992). pp. 54-80.

28. "I intend my buildings to be neutral frames where men and artwork can take their own life. To achieve this, a respectful stance in front of the objects is needed". Ludwig Mies van der Rohe en conversación con Christian Norberg-Schulz . 'Una conversación con Mies van der Rohe' in NEUMEYER, Fritz. Mies van der Rohe: la palabra sin artificio: reflexiones sobre arquitectura, 1922-1968. Madrid: El Croquis, 1995. 516 p. [Original ed.: The Artless Word: Mies Van De Rohe on the Building Art. The MIT Press, 1991].

29. As an example, in the Netherlands, the Ratiobouw, which grouped together most of the organizations involved in the 
29. A título de ejemplo, en Holanda, la Ratiobouw, que agrupaba a la mayor parte de las Organizaciones dedicadas a la Industria de la Construcción, se encargó de experimentar y adaptar más de 360 'sistemas constructivos completos', cuya utilización estaba garantizada mediante contratos con el gobierno. Entre 1948 y 1951 el porcentaje de viviendas edificadas con estos sistemas pasó del 5\% al 19\% del total. [Fuente: BOSMA, Koos; VAN HOOGSTRATEN, Dorine; VOS, Martijn. Housing for the Millions: John Habraken and the SAR (1960-2000). Rotterdam: NAI Publishers, 2000. 40p.].

30. HABRAKEN, N. J. De dragers en de mensen; het einde van de massawoningbouw. Amsterdam: Scheltema \& Holkema, 1961. [Ed. en castellano: Soportes: una alternativa al alojamiento de masas. Madrid: Alberto Corazón, 1975. Trad. de Fernando Ramón].

31. "[...] since the beginning of the Century, the individual has been disregarded in all housing projects". HABRAKEN, N. J. 'You can't design the ordinary' en Architectural Design. (April, 1971). pp. 230-231

32. "Typology is basically systemic". HABRAKEN, N. J. en "Type as social agreement" una ponencia presentada en el Third Asian Congress of Architects. Seoul, Korea. Nov. 1988. Department of Architecture, MIT.

33. HABRAKEN, N. J.; TEICHER, Jonathan (ed.). The Structure of the Ordinary: Form and Control in the Built Environment. Cambridge, Mass: MIT Press, 1998. 284 p.

34. "Assessing the capacity of a given space is such a common operation that we hardly pause to think of it. Yet it is worth attention as well as formalization. Capacity of a space links a given form to function. But it differs in two ways from the tired form-follows-function routine. To begin with, the form must be there first. Secondly, it relates the form not to one function but to a number of possible alternative functions. [...] We do not decide on function but evaluate the form." HABRAKEN, $\mathrm{N}$. J. 'Tools of the Trade: Thematic Aspects of Designing. Draft report. Enenro 1996. 27 p. (8. Capacity vs. Function) [Disponible en: www.habraken.com/html/tools_of_the_trade.html] 35. En sus años como profesor en el MIT Habraken llegó a desarrollar un programa informático alternativo a los sistemas de dibujo basados en CAD llamado Formsheet (Design Data Management) que puede considerarse el precedente de los sistemas BIM (Building Model Information) que incluyen un protocolo de permisos de modificación y de información de estos cambios, y que reproducen el concepto de 'niveles de control' en el propio proceso de diseño. 36. Interview with Habraken (NAI, Rotterdam, 14 de Octubre 1997) citado en: BOSMA, K. et al. Op. cit. 104 p.

37. La relación entre el trabajo de ambos arquitectos se menciona brevemente en el libro que Banham dedicó al concepto de 'Megaestructura', especialmente para señalar al diferencia de actitud entre un condescendiente Le Corbusier que permite "que la clase baja se valiera por sí misma a la hora de decidir los detalles" y un preocupado Habraken que pretende "que los ciudadanos comunes no sigan sintiéndose alienados en una textura urbana en cuya creación no han intervenido". BANHAM, Reyner. Megastructure: Urban Futures of the Recent Past. London: Thames and Hudson, 1976. pp. 9-10. [Ed. en castellano: BANHAM, Reyner. Megaestructuras: futuro urbano del pasado reciente. Barcelona: Gustavo Gili, 1978].

38. Ibídem. pp.105-106.

39. BAKEMA, J. "John, you really need to explain this to me. What's the difference between a support and an ordinary skeleton? We've been making skeletons for a long time, and Le construction industry, undertook the experimentation and adaptation of more than 360 'complete building systems', whose use was guaranteed through contracts with the government. Between 1948 and 1951 the percentage of houses built with these systems rose from $5 \%$ to $19 \%$ of the total. [Source: BOSMA, Koos; VAN HOOGSTRATEN, Dorine; VOS, Martijn. Housing for the Millions: John Habraken and the SAR (1960-2000). Rotterdam: NAI Publishers, 2000. 40p.].

30. HABRAKEN, N. J. De dragers en de mensen; het einde van de massawoningbouw. Amsterdam: Scheltema \& Holkema,

1961. [Spanish ed.: Soportes: una alternativa al alojamiento de masas. Madrid: Alberto Corazón, 1975. Translation: Fernando Ramón].

31. "[...] since the beginning of the Century, the individual has been disregarded in all housing projects". HABRAKEN, N. J.

'You can't design the ordinary' in Architectural Design. (April, 1971). pp. 230-231.

32. “Typology is basically systemic.” HABRAKEN, N. J. in “Type as social agreement" a paper presented at the Third Asian

Congress of Architects. Seoul, Korea. Nov. 1988. Department of Architecture, MIT.

33. HABRAKEN, N. J.; TEICHER, Jonathan (ed.). The Structure of the Ordinary: Form and Control in the Built Environment. Cambridge, Mass: MIT Press, 1998. 284 p.

34. "Assessing the capacity of a given space is such a common operation that we hardly pause to think of it. Yet it is worth attention as well as formalization. Capacity of a space links a given form to function. But it differs in two ways from the tired form-follows-function routine. To begin with, the form must be there first. Secondly, it relates the form not to one function but to a number of possible alternative functions. [...] We do not decide on function but evaluate the form." HABRAKEN, N.

J. “Tools of the Trade: Thematic Aspects of Designing". Draft report. January 1996. 27 p. (8. Capacity vs. Function) [Available at: www.habraken.com/html/tools_of_the_trade.html]

35. In his years as a professor at MIT, Habraken came to develop an alternative software to the CAD based drawing systems, called Formsheet (Design Data Management) which can be considered the precedent of the BIM systems (Building Model Information) including a protocol of permissions to modify and access to the information from these changes, and which reproduced the concept of 'control levels' in the design process itself. 36. Interview with Habraken (NAI, Rotterdam, October 14, 1997) cited in: BOSMA, K. et al. Op. cit. 104 p.

37. The relation between the work of both architects is briefly mentioned in the book that Banham dedicated to the concept of 'Megastructure', specially to point out the difference between the approach of a condescending Le Corbusier that "was prepared to let the lower orders to shift for themselves over the details" and a concerned Habraken claiming that "ordinary citizens shall no longer feel alienated from a urban fabric whose creating has been neither their pleasure nor they responsibility". BANHAM, Reyner. Megastructure: Urban Futures of the Recent Past. London: Thames and Hudson, 1976. pp.9-10. [Spanish ed.: BANHAM, Reyner. Megaestructuras: futuro urbano del pas reciente. Barcelona: Gustavo Gili, 1978].

38. Ibídem. pp. 105-106.

39. BAKEMA, J. "John, you really need to explain this to me. What's the difference between a support and an ordinary skeleton? We've been making skeletons for a long time, and Le Corbusier did the same. Surely there is no difference?" 
Corbusier did the same. Surely there is no difference?" Según relata Frans van der Werf en Open Ontwerp. Rotterdam: 010 Publishers, 1993, (disponible solo en holandés) y se recoge en: BOSMA, K. et al. Op. cit. 228 p.

40. "The support was not a neutral envelop but an autonomous, designed structure that offered clues to its completion accor-

ding to the occupant's wishes." (énfasis añadido). HABRAKEN, N. J. en: BOSMA, K. et al. Op. cit. 304 p.

"Capacity analysis links designing on different levels. It offers a means to assure the hierarchical continuity of the environmental form without freezing it from top to bottom. For a form to have meaningful capacity at all, it should not be neutral. A well articulated higher level form suggests possible uses." (énfasis añadido). HABRAKEN, N. J. 'Tools of the Trade: Thematic Aspects of Designing'. Draft report. (January, 1996). [Disponible en: www.habraken.com/html/tools_of_the_trade.html]. 41. HABRAKEN, J.N. en 'Define and let go / An interview with John Habraken'. Productive Uncertainty OASE. n.85. Rotterdam: NAi Publishers, 2011. 10 p.

42. "I realize now that I have done too little to promote an understanding of my work. I underestimated its translation into architecture. That's something that we simply took for granted". SAR Archive, box a6, carta de Habraken a W. van Tijen fechada el 6 de Noviembre de 1996. Citado en: BOSMA, K. et al. Op. cit. $306 \mathrm{p}$.
Acording to Frans van der Werf in Open Ontwerp. Rotterdam: 010 Publishers, 1993, (only available in Dutch) and compiled in: BOSMA, K. et al. Op. cit. 228 p.

40. "The support was not a neutral envelop but an autonomous, designed structure that offered clues to its completion according to the occupant's wishes." (emphasis added). HABRAKEN, N. J., in: BOSMA, K. et al. Op. cit. 304 p.

"Capacity analysis links designing on different levels. It offers a means to assure the hierarchical continuity of the environmental form without freezing it from top to bottom. For a form to have meaningful capacity at all, it should not be neutral. A well articulated higher level form suggests possible uses." (emphasis added). HABRAKEN, N. John. 'Tools of the Trade: Thematic Aspects of Designing. Draft report. (January, 1996). [Available at: www.habraken.com/html/tools_of_the_trade.html].

41. HABRAKEN, J.N. in 'Define and let go / An interview with John Habraken'. Productive Uncertainty OASE. n.85. Rotterdam: NAi Publishers, 2011. 10 p.

42. "I realize now that I have done too little to promote an understanding of my work. I underestimated its translation into architecture. That's something that we simply took for granted". SAR Archive, box a6, letter from Habraken to W. van Tijen dated November 6th, 1996. Cited in: BOSMA, K. et al. Op. cit. 306 p. 